\title{
U.S. Army Facility for the Consolidation of Low-Level Radioactive Waste
}
S. L. Stein
R. T. Hadley
J. E. Tanner
O. M. Lyso
B. L. Murphy
R. L. Gilchrist
J. C. Gillings
D. W. Murphy

December 1983

Prepared for the

U.S. Department of the Army under U.S. Department of Energy

Contract DE-AC06-76RLO 1830

Pacific Northwest Laboratory

Operated for the U.S. Department of Energy

by Battelle Memorial Institute 


\title{
NOTICE
}

The views, opinions, and/or findings contained in this report are those of the authors and should not be construed as an official Department of the Army position, policy, or decision, unless so designated by other documentation.

\section{DISCLAIMER}

This report was prepared as an account of work sponsored by an agency of the United States Government. Neither the United States Government nor any agency thereof, nor any of their employees, makes any warranty, express or implied, or assumes any legal liability or responsibility for the accuracy, completeness, or usefulness of any information, apparatus, product, or process disclosed, or represents that its use would not infringe privately owned rights. Reference herein to any specific commercial product, process, or service by trade name, trademark, manufacturer, or otherwise, does not necessarily constitute or imply its endorsement, recommendation, or favoring by the United States Government or any agency thereof. The views and opinions of authors expressed herein do not necessarily state or reflect those of the United States Government or any agency thereof.

\author{
PACIFIC NORTHWEST LABORATORY \\ operated by \\ BATTELLE \\ for the \\ UNITED STATES DEPARTMENT OF ENERGY \\ under Contract DE-AC06-76RLO 1830
}

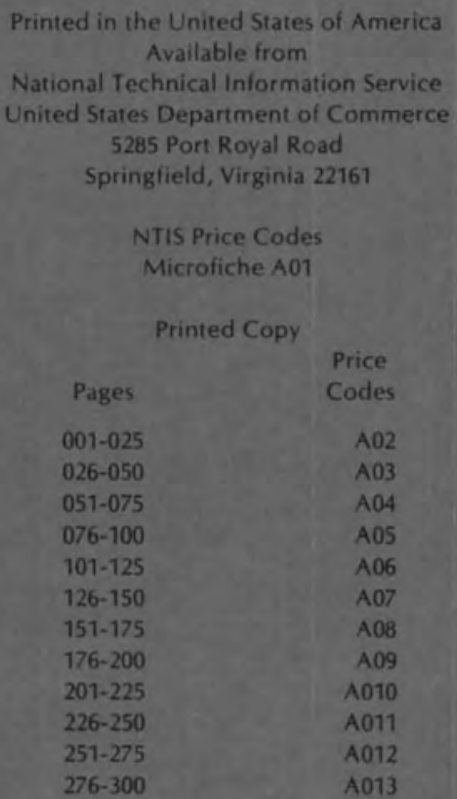




\section{U. S. ARMY FACILITY FOR THE CONSOLIDATION OF LOW-LEVEL RADIOACTIVE WASTE}
S. L. Stein
J. E. Tanner
B. L. Murphy
J. C. Gillings
R. T. Hadley
O. M. Lyso
R. L. Gilchrist (a)
D. W. Murphy

December 1983

Prepared for the

U. S. Department of the Army under U. S. Department of Energy Contract DE-AC06-76RLO 1830

Pacific Northwest Laboratory Richland, Washington 99352

(a) Hydro Nuclear Services Richland, Washington

(b) Reynolds Electric and Engineering Company Las Vegas, Nevada 
1 


\section{$\underline{\text { ABSTRACT }}$}

A preliminary study of a waste consolidation facility for the Department of the Army's low-level radioactive waste was carried out to determine a possible site and perform a cost-benefit analysis. Four sites were assessed as possible locations for such a facility, using predetermined site selection criteria. To assist in the selection of a site, an evaluation of environmental issues was included as part of each site review. In addition, a preliminary design for a waste consolidation facility was developed, and facilities at each site were reviewed for their availability and suitability for this purpose. Currently available processes for volume reduction, as well as processes still under development, were then investigated, and the support and handling equipment and the staff needed for the safe operation of a waste consolidation facility were studied. Using current costs for the transportation and burial of low-level waste, a cost comparison was then made between waste disposal with and without the utilization of volume reduction. Finally, regulations that could affect the operation of a waste consolidation facility were identified and their impact was assessed. 


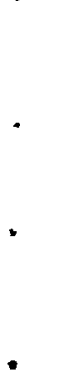




\section{CONTENTS}

ABSTRACT

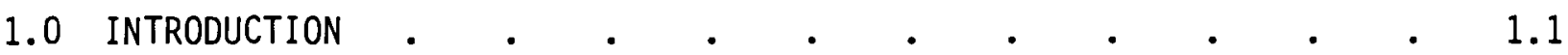

1.1 CURRENT PRACTICES AND PROBLEMS IN WASTE DISPOSAL • $• . \quad \cdot 1.1$

1.2 AN ALTERNATIVE FOR WASTE PREPARATION . . . . . . 1.3

1.3 PURPOSE OF THE CURRENT STUDY . . . . . . . . . . . 1.4

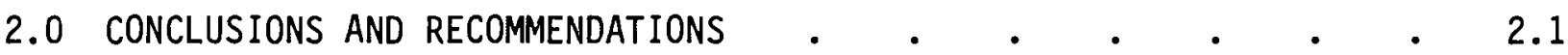

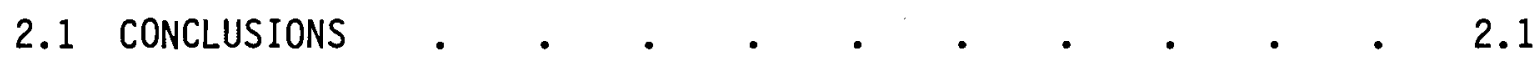

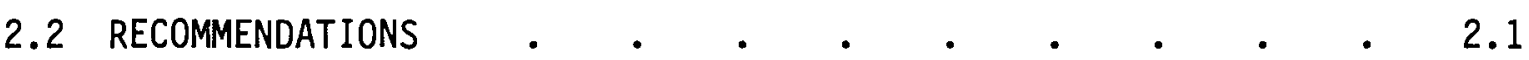

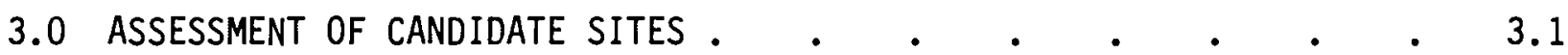

3.1 DESCRIPTION OF THE FOUR SITES . • • • • • • • • • 3.1

3.1.1 Aberdeen Proving Ground . . . . . . 3.1

3.1.2 Anniston Army Depot . . . . . . . . . 3.4

3.1.3 Sierra Army Depot . . . . . . . . 3.7

3.1.4 Weldon Spring Chemical Plant . . . . . 3.10

3.2 CRITERIA FOR ASSESSING THE SITES • • • • • • $\quad$ • 3.12

3.3 ASSESSMENT PROCEDURE AND FINDINGS • . • . • . . . 3.14

3.3.1 Proximity and Accessibility . . . . . . 3.14

3.3.2 Availability of an Existing Facility . . . . 3.18

3.3.3 Resource Availability . . . . . . . 3.20

3.3.4 Institutional Considerations . . . . . . 3.21

3.3.5 Environmental Considerations . . . . . 3.21

3.4 SUMMARY ASSESSMENT OF CANDIDATE SITES • • • • • • $\quad 3.22$

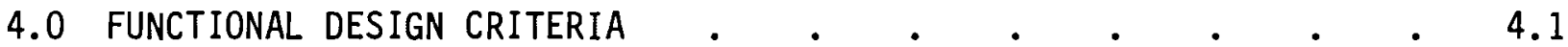

4.1 PROPOSED DESIGN FOR A WASTE CONSOLIDATION FACILITY • • 4.1

4.1.1 General Requirements . . . . . . . . 4.1 
4.1.2 Functional Requirements . . . . . . . 4.3

4.1.3 Architectural-Structural Considerations $\quad 4.4$

4.1.4 Mechanical Design Features . . . . . . . 4.5

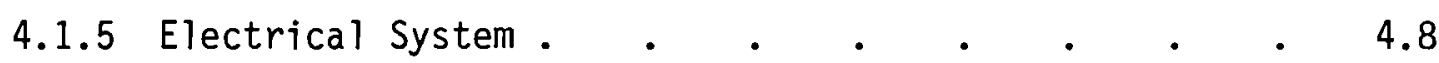

4.2 RENOVATION AND REDESIGN OF EXISTING FACILITIES $\quad$ • $\quad$ • 4.8

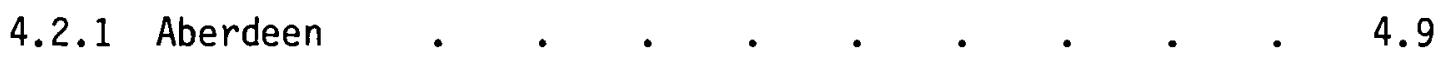

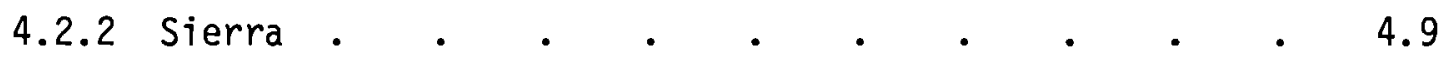

4.2.3 Weldon Spring . . . . . . . . . . 4.10

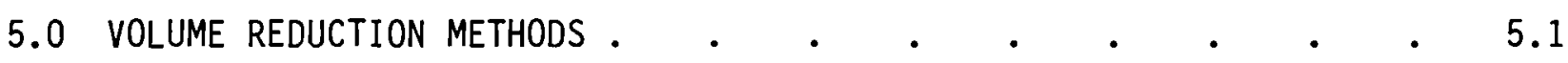

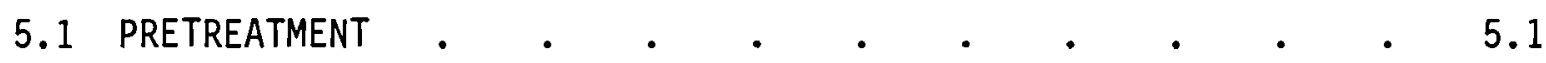

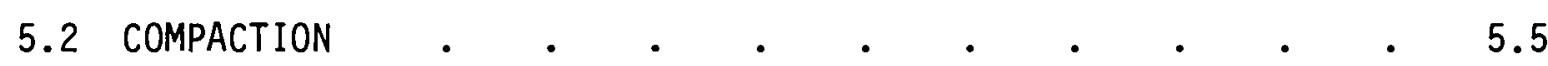

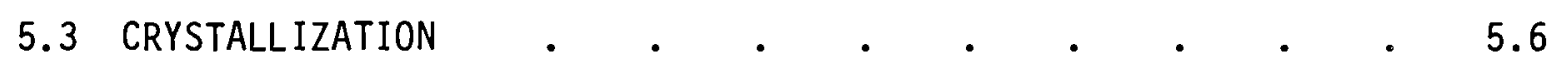

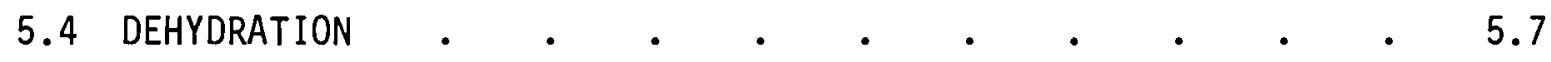

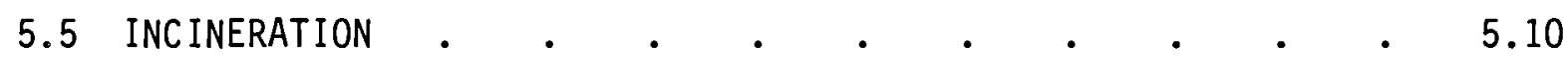

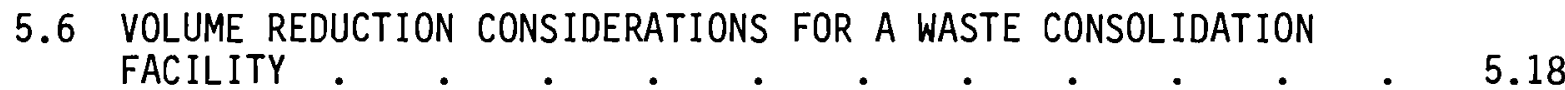

6.0 WASTE MANAGEMENT OPERATIONS, EQUIPMENT, AND STAFFING $\quad$ • 6.1

\begin{tabular}{l}
6.1 OVERVIEW OF FACILITY OPERATIONS AND WASTE-HANDLING \\
EQUIPMENT NEEDS \\
\hline
\end{tabular}

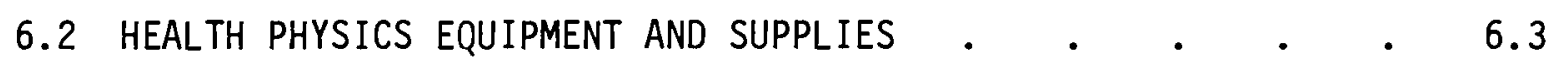

6.2.1 Air-Sampling and Air-Monitoring Equipment . . . 6.3

6.2.2 Survey and Personnel-Monitoring Equipment . . . 6.4

6.2.3 Equipment for Assessing Direct-Radiation Levels . $\quad 6.5$

6.2.4 Protective Clothing and Other Supplies $\quad$ • $\quad$. $\quad$. 6.8

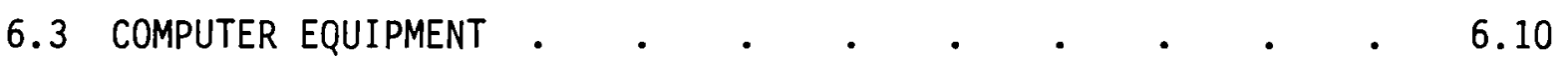

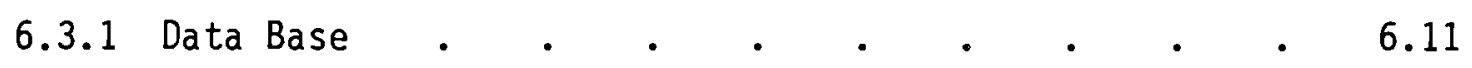

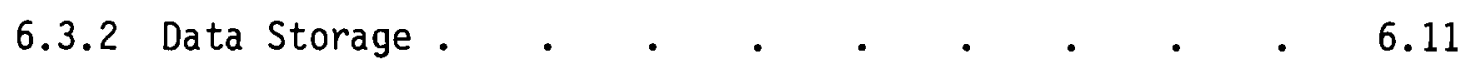


6.3.3 Interactive Communications . . . . . . 6.12

6.3.4 Word Processing . . . . . . . . 6.12

6.3.5 High-Quality Printer . . . . . . . . 6.12

6.3.6 Optional Features . . . . . . . . 6.12

6.3.7 Suggested Computer Systems . . . . . . . 6.13

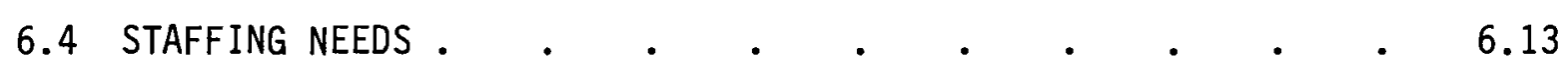

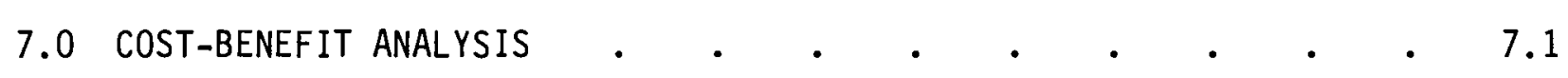

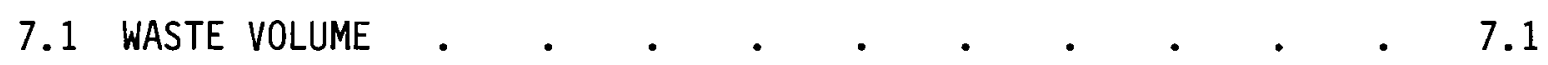

7.2 TRANSPORTATION AND DISPOSAL COSTS • • • • • • •

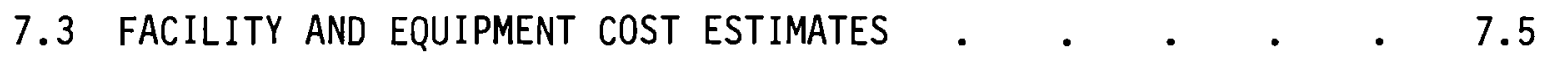

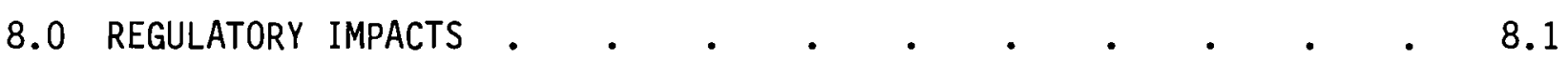

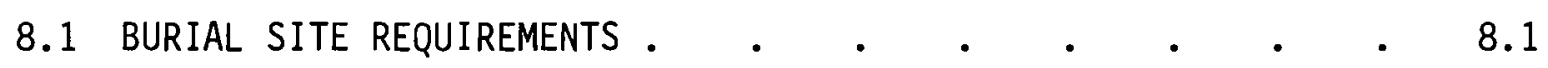

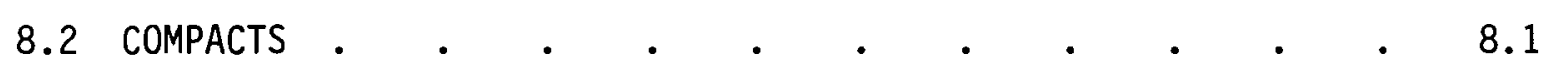

8.2.1 State and Regional Low-Level-Waste Management . $\quad 8.3$

8.2.2 Regulatory Authority . . . . . . . 8.3

8.2.3 Import Restrictions . . . . . . . 8.3

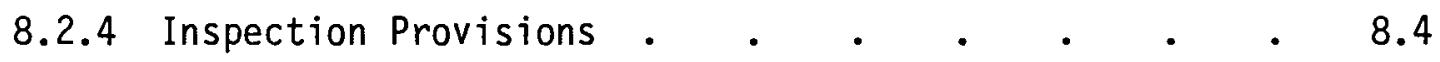

8.3 STATE AND NUCLEAR REGULATORY COMMISSION REGULATIONS • $\quad 8.4$

8.4 DEPARTMENT OF TRANSPORTATION REGULATIONS • • • • $\quad 3.5$

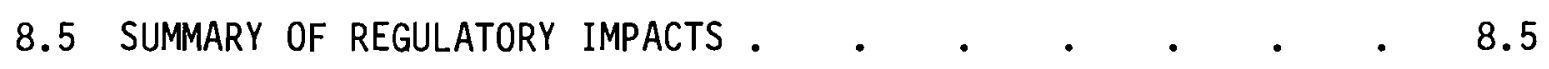

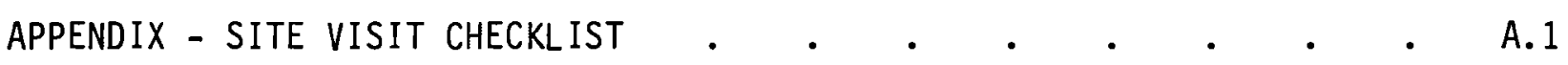

REFERENCES • • • 


\section{FIGURES}

3.1 Location of Four Candidate Sites for Proposed Waste Consolidation Facility and Three Currently Available

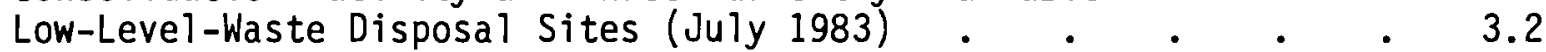

4.1 Proposed Design for a Radioactive-Waste Consolidation Facility $\quad 4.2$

7.1 One-Way Shipping Charges for Low-Level-Waste Shipments Travelling More Than 1000 Miles

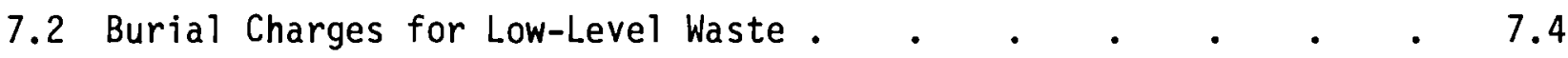

8.1 Proposed State Compact Regions as of July $1983 \quad$. $\quad$. $\quad$ e $\quad 8.2$

\section{TABLES}

3.1 Summary of Findings from the Review of Four Candidate Sites . $\quad 3.15$

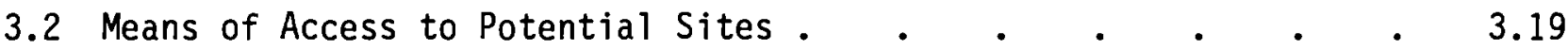

3.3 Site Ranking for a Central Consolidation Facility . • • • • $\quad 3.24$

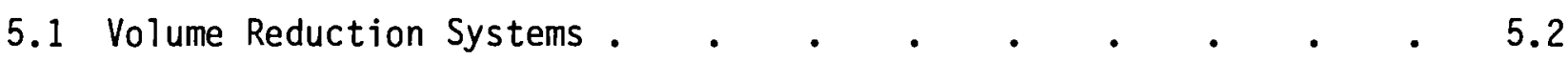

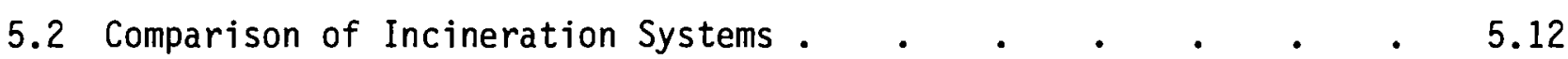

6.1 Characteristics of High-Sensitivity Portal Monitors . • . 6.6

6.2 Sample List Prices for Health Physics Survey and Laboratory Counting Instruments $\quad . \quad . \quad . \quad . \quad . \quad . \quad 0.7$

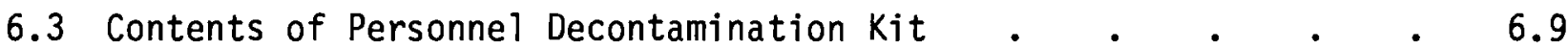

6.4 Example List Prices for Health Physics Supplies . . . . . 6.10

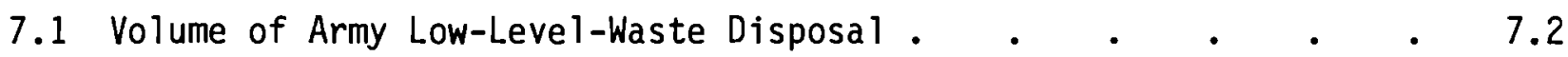

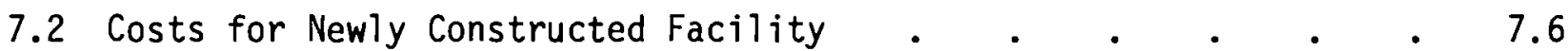

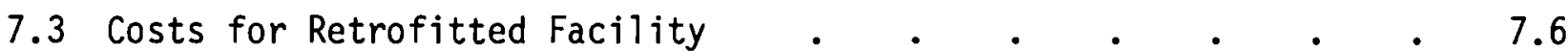

7.4 Unit Construction Costs for Major Building Components . $\quad$ • $\quad$ - 7.7

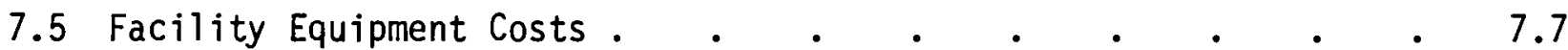

\begin{tabular}{l}
7.6 Cost Comparison for Disposal of Wastes With and Without Volume \\
Reduction. \\
\hline
\end{tabular}

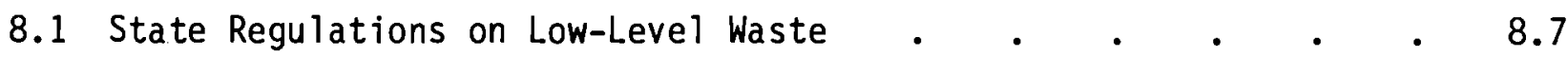




\subsection{INTRODUCTION}

The operations of the U. S. Department of the Army (DA) in the continental United States and abroad generate various types of low-level radioactive waste (LLW). The waste originates from radioisotopes used in medical and research facilities and from field equipment containing radioactive material. Low-level radioactive waste is usually described as having 1) sufficiently low levels of beta-gamma activity so that no special provisions must be made for heat removal, and 2) sufficiently low levels of penetrating radiation so that no or only minimal biological shielding or remote handling is necessary for personnel protection. Low-level waste is also generally considered to contain less than $10 \mathrm{nCi} / \mathrm{g}$ of transuranic alpha-emitters (e.g., uranium, americium).(a)

The LLW generated by the Army is typically packaged at the point of generation and sent either to a broker or directly to a commercial waste disposal site for burial. However, three considerations have prompted the Army to examine alternatives to the current practices: 1) problems in ensuring the proper packaging of waste prior to its shipment for disposal; 2) the limited number of sites currently available for waste disposal and the potential for future restrictions on the use of those sites; and 3) the rapidiy increasing costs of waste disposal, which follow from (1) and (2). In 1981, therefore, the Armament Materiel Readiness Command (ARRCOM) studied the practicability of establishing a central facility for the consolidation of Army wastes. The current report describes a follow-up study requested by ARRCOM and performed by the Pacific Northwest Laboratory (PNL) ${ }^{(b)}$ to further assess the requirements and the cost-effectiveness of such a facility.

\subsection{CURRENT PRACTICES AND PROBLEMS IN WASTE DISPOSAL}

Currently, the nation relies on three burial sites (Barnwell, South

(a) NRC has increased the limit of $10 \mathrm{nCi} / \mathrm{g}$ of transuranics for low-level waste to $100 \mathrm{nCi} / \mathrm{g}$.

(b) Operated for the Department of Energy by Battelle Memorial Institute. 
Carolina; Beatty, Nevada; and Hanford, Washington) for the disposal of all commercial, non-defense-related LLW. The U. S. Nuclear Regulatory Commission (NRC), the U. S. Department of Transportation (DOT), and the individual burial sites impose strict requirements on the handling and disposal of LLW. Army shipments of LLW are governed also by DA regulations, with the Commander of ARRCOM ultimately responsible for the management of radioactive waste. Radiation protection officers are responsible for packaging the LLW at the more than one hundred Army and Army licensee sites where these wastes are generated.

On occasion, generators of LLW have failed to comply completely with packaging and transportation requirements, with the following consequences:

- The burial site to which the LLW was shipped has rejected the waste package or temporarily closed the site to all packages from that waste generator. The rejection of a package causes increased costs for the extra transportation and repackaging of the waste, and increased exposures for the personnel handling the waste. The temporary closure of a site requires that the generator either pay transportation costs to more distant sites or have a facility for the safe, long-term storage of LLW. Many Army licensees do not have such facilities.

- At the Beatty burial site, third-party inspections are now required by the state of Nevada. These inspections sharply increase the generator's disposal costs.

In addition, the states in which the burial sites are located have at times temporarily closed the sites because federal regulatory agencies were not properly enforcing regulations or not imposing sanctions on waste generators and shippers who failed to comply with all applicable regulations (National Governors' Association Task Force on Low-Level Radioactive Waste Disposal 1980).

The 1 imited number of disposal sites causes additional problems for LLW generators. Because the Army is competing with commercial generators for limited burial space at Barnwell, the Barnwell site now limits the amount of LLW it will accept from each waste generator, and further volume restrictions are expected. The Barnwell quota requires that careful consideration be given 
to the items shipped there for burial. Currently, the Army-generated waste shipped to Barnwell consists mostly of contaminated soil from Aberdeen, Maryland, which is cost-prohibitive to ship to either Beatty or Hanford. The remainder of the Army's LLW must be disposed of at one of the other two sites, which currently have no restrictions on the amount of waste accepted from each generator. Although the cost of transporting waste to Beatty is less than the transportation cost to Hanford, the third-party inspections required by the state of Nevada have driven disposal costs up so much that the disposal of LLW is more cost-effective at Hanford than at Beatty.

The future use of the three burial sites is not completely assured. State government officials in Nevada have made several attempts in recent years to permanently close the waste burial site at Beatty. The Hanford and Barnwell sites are expected to continue to operate and to accept wastes from all over the country; however, their continued acceptance of wastes may depend on the willingness of other states, or of compact regions for LLW management, ${ }^{(a)}$ to develop other LLW burial sites. If the states or compact regions take no action, or if South Carolina and Washington State perceive that inadequate progress is being made toward the development of other sites, the political climate in the two states would probably force action to make the disposal of out-of-state or out-of-region LLW more difficult and costly than it is now (Spellman 1982). Furthermore, compact regions may have the authority to restrict the volume of waste disposed of in the region or to prohibit the importation of LLW into the region for disposal.

Because of all these constraints, the Army is considering ways of reducing the volume of LLW sent for burial and of ensuring the proper packaging of the waste.

\subsection{AN ALTERNATIVE FOR WASTE PREPARATION}

The concept of establishing a central facility for the consolidation of

(a) The Low-Level Radioactive Waste Policy Act of 1980 authorizes the individual states to associate together in regional compacts to handle the disposal of LLW. Under the Act, the burden for LLW disposal is given to the states and, implicitly, to the regional compacts. 
LLW has been studied previously by ARRCOM. A conclusion of that study was that it might be desirable to have one or more satellite facilities supporting a central facility. The central facility would house the primary volume reduction equipment, and the satellite or satellites would be waste packaging facilities that might also house a small compaction device. Low-level waste received at a satellite facility would be repackaged for the purpose of consolidating the waste and of meeting any packaging and transportation requirements imposed by a specific burial site but not specified in Title 49 of the Code of Federal Regulations ( 49 CFR). The repackaged waste would then be sent from the satellite facility directly to the waste disposal site. Any shipments of LLW that needed a type of volume reduction that the satellite could not handle (e.g., solidification) would be sent to the central facility before being shipped to a disposal site.

The size of the central and satellite facilities would be based on an analysis of the waste forms and quantities generated in recent years, and on projections of future waste volumes. However, in the event that the Army was precluded from shipping some of its waste for disposal because of the closure of a burial site or restrictions imposed by a compact region, storage space capable of housing up to a year's volume of waste would also be needed.

\subsection{PURPOSE OF THE CURRENT STUDY}

The objectives of the study reported on here were to:

- assess four candidate sites for central and satellite waste consolidation facilities

- provide a basic design for a central facility and assess the usability of existing facilities at each of the four sites

- research state-of-the-art volume reduction techniques

- describe how a central waste consolidation facility would operate and assess the staffing and equipment needed for its operation

- perform cost-benefit analyses for waste disposal with and without volume reduction 
- identify regulations that could affect the operation of a waste consolidation facility.

Conclusions and recommendations are presented in Section 2.0. The four sites evaluated and the methods used in the evaluation are discussed in Section 3.0. The preliminary functional design criteria for a facility and the assessment of existing facilities are detailed in Section 4.0. Volume reduction methods are discussed in Section 5.0. Section 6.0 presents the recommended facility operation and the assessment of staffing and equipment needs. Waste volume and disposal cost projections are given in Section 7.0, and current and potential regulatory impacts are presented in Section 8.0. 
.

. 


\subsection{CONCLUSIONS AND RECOMMENDATIONS}

\subsection{CONCLUSIONS}

1. There appears to be sufficient cost incentive to justify a central consolidation facility. It may also be cost-beneficial to develop one or more satellite facilities. A preliminary cost analysis indicates that the proposed facilities would save the Army a minimum of about $\$ 800,000$ per year in waste-packaging, transportation, and burial costs.

2. Such facilities would cost more to establish at Anniston or Weldon Spring than at Aberdeen or Sierra.

3. The Army would be required to obtain an NRC license for the operation of a waste consolidation facility.

4. A preliminary review indicates that an environmental impact statement may not have to be written. An environmental evaluation, or at most an environmental assessment, may be all that is needed. In either case, compliance with the National Environmental Policy Act is required.

\subsection{RECOMMENDATIONS}

1. A new building for use as a central waste consolidation facility should be erected at the Edgewood area of the Aberdeen Proving Ground.

2. The cost-benefit of a satellite facility should be examined in greater detail, and the Sierra Army Depot should be considered further as the location for such a facility.

3. More rigorous estimates of future waste generation rates should be performed, as should further analysis of the optimum facility design and facility costs.

4. A central facility should include the following equipment: a shredder, compactor, dryer, and/or incinerator. A satellite facility should include the following equipment (which will be considerably smaller than the central facility's equipment): a shredder, compactor, and dryer.

5. An environmental evaluation and a license application should be prepared early in the planning stage of the project. 


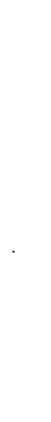




\subsection{ASSESSMENT OF CANDIDATE SITES}

The Army identified four sites as potential locations for a central waste consolidation facility or a satellite facility. These sites were selected from among all of the Army's Development and Readiness Command (DARCOM) bases according to the following criteria. Bases located far from the three currently used waste burial sites (e.g., the Seneca Depot in upstate New York) were eliminated from consideration, as were those not close to the normal transportation network followed by trucking companies (e.g., the Yuma Proving Ground in Arizona). Some consideration was also given to how near each base was to a major metropolitan area (a negative factor) and to the largest generators of LLW (a positive factor).

The four sites selected for further assessment were the Aberdeen Proving Ground in Maryland, the Anniston Army Depot in Alabama, the Sierra Army Depot in California and the Weldon Spring Chemical Plant in Missouri. The locations of these sites and of the three burial grounds are shown in Figure 3.1. The four sites are described in this section, along with the criteria used to assess them and the results of the evaluation.

\subsection{DESCRIPTION OF THE FOUR SITES}

The location of each site, its topography, climate, hydrology, and land use, and the effect of current site activities on the environment are described below, based on the installations' respective environmental impact assessments (DA 1978, 1982, 1979, 1976).

\subsubsection{Aberdeen Proving Ground}

The Aberdeen Proving Ground is located in Hanford County, Maryland. The Chesapeake Bay, Gundpowder River, and Bush River comprise approximately half of the reservation's 79,000 acres. The Aberdeen area of the installation covers 17,000 acres in the southeastern section of the county and is 30 miles northeast of Baltimore and 3 miles southeast of the town of Aberdeen. The Edgewood area of the installation covers 13,000 acres in the southwestern section of the county and is 21 miles northeast of Baltimore. 


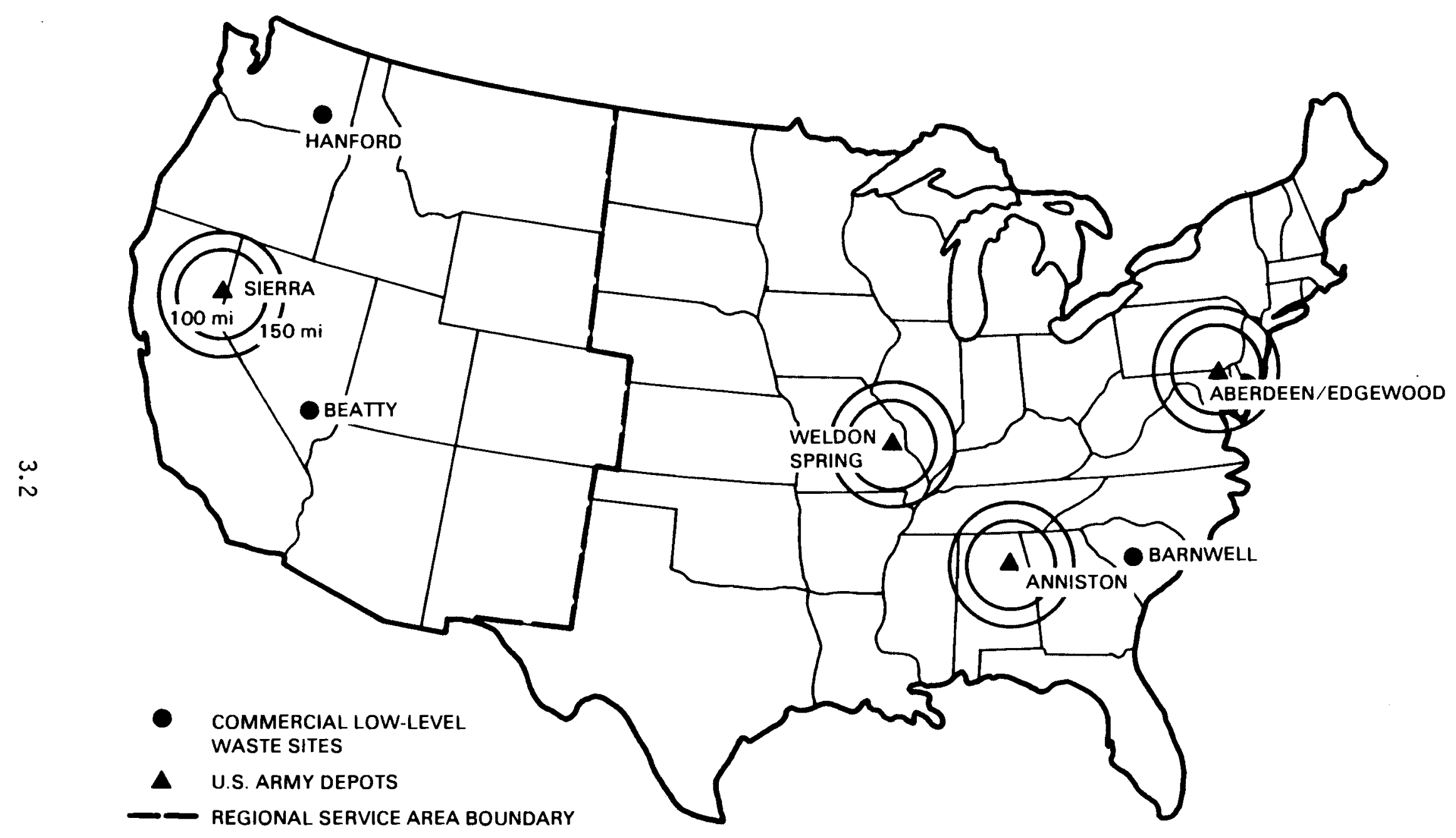

FIGURE 3.1. Location of Four Candidate Sites for Proposed Waste Consolidation Facility and Three Currently Available Low-Level-Waste Disposal Sites (July 1983) 
In $1975,4,122,000$ people resided in Hanford County. The 1980 population of the town of Aberdeen was 11,533, and that of the town of Edgewood was 19,455. The population of the Aberdeen Proving Ground was 14,654 in 1976, and the regional population within commuting distance of the installation was approximately 88,000 .

\subsubsection{Topography}

Much of the Aberdeen Proving Ground, which is in the northern edge of the Atlantic coastal plain, either consists of marshy, wooded terrain or lies underwater. The remainder of the installation is low-lying, flat-to-gentlyrolling country. The coastal plain formations are composed of silt, clay, 1 imestone, sand, and gravel of both marine and continental origin. The crystalline rocks north of the Aberdeen Proving Ground have been folded, faulted, and intruded. Faults are also found beneath the coastal plain and in the outcrop crystalline rock to the west of Aberdeen. The largest major fault near the Aberdeen area of the Proving Ground is the Mill Green Fault to the north and northwest. All faults in the crystalline rock are inactive. Extremely minor seismic events have occurred in the unconsolidated sediments of the coastal plain, but they have had little or no effect on surface features or man-made objects.

Soils of the Aberdeen Proving Ground range from 0 to 5 feet above the water table and have low-to-moderate permeability. The generally low relief and high water table of the installation result in the wide distribution and dominance of bottomland woodland species. Beech, often dominant in Maryland bottomlands, is found in dense stands throughout the installation. Open areas that are either intensely or periodically mowed are a mixture of many types of grasses, forbs, and herbaceous weeds.

\subsubsection{Climate}

The average temperature at the Aberdeen Proving Ground is $56^{\circ} \mathrm{F}$, with an average high of $88^{\circ} \mathrm{F}$ in the summer and low of $18^{\circ} \mathrm{F}$ in the winter. Rainfall averages 50 inches annually, and the growing season is approximately 180 days. On the average, 30 thunderstorms per year occur in the Chesapeake Bay area and 
often bring damaging high winds. The state of Maryland usually experiences one or two tornadoes each year; further, the area may be influenced by a hurricane approximately once a year, usually in August or September.

\subsubsection{Hydrology}

Nearly $80 \%$ of the installation's land area is marshy lowlands. Another 36,700 acres consist of the waters of the Chesapeake Bay and the many creeks that drain the lowlands. Two excellent aquifers overlie the crystalline rocks beneath the Aberdeen Proving Ground. The installation's entire water supply is from surface waters and in-house wells on Army land.

\subsubsection{Land Use}

Forty-two percent of the land area of the Aberdeen Proving Ground is classified as cleared area. The remaining areas are woodlands and wetlands. Lawns and periodically mowed fields together compose 7374 acres, compared with the 26,225 acres of forest and successional woodlands. There are five wildlife refuges and 50 commercial fishing and crabbing areas within the installation boundaries. The Maryland darter and the tiger salamander are two endangered species that have been found near the site.

\subsubsection{Effect of Current Site Activities on the Environment}

Over the past 60 years the U.S. Army has used the Aberdeen Proving Ground for research on the development and testing of ordnance and chemical weapons. As a consequence, extensive land and water areas are contaminated with unexploded ordnance and chemical compounds. Contaminated range areas include the Abbey Point area, Poverty Island, and the old bombing area. Chemically contaminated areas include $J$ Field, 0 Field, and the Westwood area. Areas that are lightly contaminated (with unexploded ordnance or chemicals) or that may be contaminated in the future include the Land Training Area, F Field, and the Main Front.

\subsubsection{Anniston Army Depot}

The Anniston Army Depot is located in Calhoun County in east-central 
Alabama. It is approximately 60 miles east of Birmingham and 5 miles west of the city of Anniston. It is bordered on the north by the Fort McClellan Military Reservation; the Coosa River Storage Annex is located 12 miles to the south.

The distribution of Calhoun County's approximately 18,400 residents is 35\% rural and 65\% urban. In 1978, the Anniston Army Depot employed 5079 personnel. Of this number, 4890 were civilians, making the depot the largest single employer in the county.

\subsubsection{Topography}

The area comprising the depot consists of rolling land, low hills, and valleys. The elevation varies by about 350 feet from the lowest to the highest point. The depot covers 15,200 acres and includes two lakes of 5.5 acres and 36.5 acres. Approximately $70 \%$ of the area is woodland. The area of the Coosa River Storage Annex consists of rolling land along the central and eastern portions and mountainous land along the northern and western portions. The annex covers 3000 acres and is mostly woodland area.

\subsubsection{Climate}

The depot and annex are located in a region that has a moist, subtropical climate. Uniformly high temperature and humidity characterize the summer months, while the winter months are generally mild with many wet days. The average annual rainfall is 53.4 inches, with the heaviest rains occurring in the winter and spring. Summer rains are caused primarily by thunderstorms, but droughts of more than 2 to 3 weeks duration are rare. The average annual temperature is $62.3^{\circ} \mathrm{F}$, with the coldest month averaging $45.9^{\circ} \mathrm{F}$ and the hottest month averaging $78.8^{\circ} \mathrm{F}$.

\subsubsection{Hydrology}

In addition to the two lakes, the Anniston Army Depot has twenty-four 0.25-acre man-made ponds constructed specifically for fire protection and watering cattle and wildlife. Depot lands include very few streams. The 
great thickness and nonporous character of the rock units form a poor aquifer except where fractures permit some movement of groundwater.

\subsubsection{Land Use}

The depot includes 1964 acres of improved grounds (including ammunition storage magazines), 11,392 acres of woodlands, and 1853 acres of pasture and/or buildings.

Both the depot and the annex support a variety of large and small mammals, birds, and aquatic wildlife. In addition, beef cattle are grazed on specific acreage through a lease of the grazing rights. The depot is listed as a potential habitat for a number of legally protected mammals, birds, reptiles, and fish. However, there have been no confirmed sightings of any of these species at the depot. No known archaeological or historical sites are located at the depot.

\subsubsection{Effect of Current Site Activities on the Environment}

The operations and facilities of the Anniston Army Depot emit varying amounts of both air and water pollutants. All but two of these operations have abatement equipment that reduces the effluent volume to the degree needed to obtain the Alabama State Air Pollution Control Commission's permission to operate. The remaining two operations, ammunition burning and demolition, release only minor amounts of pollutants to the atmosphere.

No refuse-burning operations are located at the depot or annex. All refuse is sold, recycled, or buried in a landfill. The depot also does not have facilities for treating concentrated chemicals that are generated as spent metal-finishing solutions. In 1978, the depot collected this chemical waste and stored it in a plastic-lined holding lagoon, which replaced the previously used earthen holding lagoon. The construction of a facility to treat this waste was scheduled to begin during 1979 to 1980 but has not yet been started.

Regulations are closely followed during activities related to the storage, preparation, and use of pesticides for the depot's pest and weed 
control programs. All operations have been studied to identify any potential environmental hazards that may adversely affect the quality of air, water, or soil on the depot. The construction of upgraded facilities required to meet all state and federal pollution standards was scheduled to begin in fiscal years 1979 and 1980, but this work has not yet been undertaken.

\subsubsection{Sierra Army Depot}

The Sierra Army Depot, located in northeastern California, contains 97,571 acres within its boundaries. This area includes approximately 60,500 acres of the Honey Lake area, which has been set aside as a wildlife preserve. The unincorporated town of Herlong, with a 1975 population of approximately 2000, lies on the depot's southern boundary.

The labor market of the Honey Lake valley includes Susanville, Janesville, Edgemont, Reno, the Sierra Army Depot, Herlong, Milford, and Doyle. The 1975 estimated area population was 143,000. The two largest population areas, Susanville and Reno, are 40 and 60 miles from the depot, respectively. In 1975, the depot employed approximately 320 military personnel and 620 civilians. A number of these persons commuted from Susanville and Reno. Of the local-area labor force of about 5000 workers, $12 \%$ were employed by the depot in 1975 .

\subsubsection{Topography}

The Sierra Army Depot is situated in the southern portion of Lassen County, California, in an area known as the Great Basin. The Sierra Nevada lies to the south; Honey Lake is on the west and northwest; the Skedaddle Mountains are to the north; and the California-Nevada state line is to the east. The geography of the area is characterized by flat, enclosed basins bordered by gently sloping sand and clay deposits that in turn are flanked by steep mountain ridges. The northern three-quarters of the depot proper occupies the old floor of a now-dry section of Honey Lake. The soil in this section of the depot is fine-textured silty clay that is subject to water erosion, especially where the land slopes. The southern one-quarter of the 
depot is on a sandy outwash deposit with soil that is not subject to water erosion because of its high infiltration rate. However, approximately 600 acres are currently affected by serious, active wind erosion and the reciprocal problem of soil drifting.

\subsubsection{Climate}

The Honey Lake valley has a moderate climate with a low relative humidity and minimal rainfall. The area undergoes distinct seasonal changes, but those changes are gradual and the seasons are not severe.

The average summer temperature ranges between $65^{\circ} \mathrm{F}$ and $100^{\circ} \mathrm{F}$. Winter temperatures occasionally fall below $10^{\circ} \mathrm{F}$, and subzero temperatures may occur in December, January, and February. Precipitation occurs principally between October and May, with an annual mean rate of 5.45 in. The prevailing wind direction ranges from the south to the northwest, and the average wind speed is $6.4 \mathrm{mph}$. Occasional strong winds of $90 \mathrm{mph}$ have been experienced.

\subsubsection{Hydrology}

Honey Lake, located to the west and northwest of the depot, is usually dry but does fill up occasionally. There is also a transitory stream on the depot, as well as several artesian wells and seeps outside the depot boundary. The source of water for the Honey Lake valley is groundwater from runoff from the Sierras and local rainfall.

The source of water for the depot is four wells ranging in depth from 500 to 800 feet. The depot discharges water into the Honey Lake groundwater basin by evaporation disposal ponds. However, groundwater surveys indicate that surface water does not reach the water-bearing aquifers that provide domestic water for the depot.

\subsubsection{Land Use}

Of the 97,571 acres that comprise the SIAD, 465 acres are improved grounds (e.g., shops and operational buildings, parking lots, and an air strip), 10,512 acres are semi-improved (e.g., warehouses, small-arms ranges, and ammunition storage areas), and 86,594 are classed as 
great thickness and nonporous character of the rock units form a poor aquifer except where fractures permit some movement of groundwater.

\subsubsection{Land Use}

The depot includes 1964 acres of improved grounds (including ammunition storage magazines), 11,392 acres of woodlands, and 1853 acres of pasture and/or buildings.

Both the depot and the annex support a variety of large and small mammals, birds, and aquatic wildlife. In addition, beef cattle are grazed on specific acreage through a lease of the grazing rights. The depot is listed as a potential habitat for a number of legally protected mammals, birds, reptiles, and fish. However, there have been no confirmed sightings of any of these species at the depot. No known archaeological or historical sites are located at the depot.

\subsubsection{Effect of Current Site Activities on the Environment}

The operations and facilities of the Anniston Army Depot emit varying amounts of both air and water pollutants. All but two of these operations have abatement equipment that reduces the effluent volume to the degree needed to obtain the Alabama State Air Pollution Control Commission's permission to

depot is on a sandy outwash deposit with soil that is not subject to water erosion because of its high infiltration rate. However, approximately 600 acres are currently affected by serious, active wind erosion and the reciprocal problem of soil drifting.

\subsubsection{Climate}

The Honey Lake valley has a moderate climate with a low relative humidity and minimal rainfa11. The area undergoes distinct seasonal changes, but those changes are gradual and the seasons are not severe.

The average summer temperature ranges between $65^{\circ} \mathrm{F}$ and $100^{\circ} \mathrm{F}$. Winter temperatures occasionally fall below $10^{\circ} \mathrm{F}$, and subzero temperatures may occur in December, January, and February. Precipitation occurs principally between October and May, with an annual mean rate of 5.45 in. The prevailing wind 
unimproved. Approximately $70 \%$ of the unimproved grounds are wildlife areas.

Three threatened and three possibly threatened wildlife species have either been sighted or are believed to inhabit the Honey Lake area. The threated species are the southern bald eagle, the American peregrine falcon, and the osprey; those that are possibly threatened include the prairie falcon, the northern long-billed curlew, and the western burrowing owl. No known historical or archaeological sites of significance are located on the depot lands.

\subsubsection{Effect of Current Site Activities on the Environment}

The sources of gaseous emissions within the Sierra Army Depot are vehicular traffic, munitions testing and demolition, and petroleum fuel consumption in the boiler plant. Major gaseous effluents include carbon monoxide, carbon dioxide, hydrocarbons, nitrogen oxides, sulfur oxides, and particulates. The Environmental Protection Agency's San Francisco Office has indicated that emissions from the depot have been within the applicable standards (DA 1979).

None of the depot's activities introduce substances into the surface or subsurface water systems. All depot sewage is processed through two treatment plants; none of the effluent seeps underground. A number of leaching fields have been developed that contain wastes from acid drains and other industrial wastes. These fields and the sewage ponds are used as a source of water by birds and mammals. However, a continuous monitoring program has not identified any negative impact on the wildlife from this use.

The Sierra Army Depot operates a landfill site for the disposal of solid wastes. The disposal of toxic wastes and liquid wastes at this site is not permitted. However, since 1972, the depot has been designated as a repository for retrograde commercial chemicals from bases in the Pacific Ocean.

The detonation of large quantities of explosives $(10,000 \mathrm{lb}$ at one time) has not caused any earthquakes or tremors in the surrounding area. However, these explosions have caused some noise pollution. 
A variety of insecticides, herbicides, and chemicals to control rodents are used on the depot for pest control. No significant episodes of nontarget pesticide poisoning are known to have occurred; however, pesticide monitoring has been limited to soil samples.

\subsubsection{Weldon Spring Chemical P1ant}

The Weldon Spring Chemical Plant, located in St. Charles County, Missouri, consists of approximately 252 acres 13 miles southwest of the city of St. Charles and 25 miles due west of St. Louis. The Missouri River is approximately 1.5 miles southeast of the site. Of the total acreage, the U.S. Army occupies 201 acres, including 32 acres of sewer easement. The remaining portion of the site is under the administration of the U.S. Department of Energy (DOE). Two towns, Weldon Spring Heights (population 135) and Weldon Spring (population 70), are approximately 2 miles northeast of the plant.

\subsubsection{Topography}

The Weldon Spring Chemical Plant lies on a ridge that separates the Missouri and Mississippi Rivers. The bedrock under the plant is made up of fractured limestone. Some dissolving of this limestone has occurred, and infiltrating water could move directly to the groundwater system through these fractures. The bedrock is overlain with a clay deposit approximately 25 to 30 feet thick. Analysis of samples from the site indicates that the clay is virtually impermeable.

The surface of the region is covered almost entirely by unconsolidated materials consisting of deposits of glacial drift and residuum from rock weathering. The beds of all the streams contain deposits of variable amounts of silt, sand, gravel, and clay. The Missouri River flood plain contains approximately 20 feet of silt overlying about 80 feet of sand and gravel. Laboratory classification of all soil samples taken from the plant area shows that the soil is generally a medium-to-stiff, slightly modeled, highly plastic, silty clay with some traces of sand and fine gravel. 


\subsubsection{Climate}

On the average, 171 tornadoes occur in the state of Missouri each year. Assuming that tornadoes within the state are randomly distributed and that $25 \%$ are of large magnitude and intensity at ground level, the frequency of tornado occurrence at any point in the state is once in 2080 years.

The upper Mississippi and Ohio valleys are regions of frequent earthquake activity. Three of the great earthquakes of known history occurred in this region near New Madrid, Missouri, which is about 150 miles south of Weldon Spring. These earthquakes occurred in 1811 and 1812 and affected about two million square miles. It has been estimated that an earthquake of $8 \%$ of the force of gravity is likely to occur at St. Louis, Missouri, at least once in a 50 -year period. At New Madrid, a force of $19 \%$ is probable in a 50 -year time span. The probability of an event such as those of 1811 and 1812 occurring is on the order of once every 10,000 years.

\subsubsection{Hydrology}

The Weldon Spring Chemical Plant is located on the Missouri-Mississippi River surface drainage divide. Surface drainage from the south and east areas of the site flows southeast to the Missouri River; drainage from the north and west areas of the site flows north to the Mississippi River. The site contains two small ponds, Ash Pond and Frog Pond, that discharge water offsite. The discharge from these ponds combines with runoff and flows to Lakes 35 and 36 in the wildlife area, from which it eventually enters the Mississippi River. A third discharge stream from the site, resulting from the plant's process sewer drainage, flows to the Missouri River. Water from raffinate pits one, two, and three, located in the DOE sector, previously entered this third stream until the drainage path was blocked in 1975.

The Weldon Spring area has three bedrock aquifers located at 60, 300, and 700 feet below the bottom of the raffinate pits. The upper two aquifers contain hard water and are not generally used as a water source. The main source of reasonably soft water is the artesian aquifer located at 700 feet. A relatively thick and impermeable clay stratum overlies the bedrock aquifers. 


\subsubsection{Land Use}

The plant itself occupies 169 acres, with an additional 32 acres of sewer easement; DOE operates the raffinate pits on approximately 51 acres. The site is bordered on the north by the August A. Busch Memorial Wildlife Area, administered by the Missouri State Department of Conservation. The U.S. Army Reserve and National Guard Training Area, under the administrative control of the Fifth U.S. Army, Fort Leonard Wood, forms the western and southern borders; agricultural land belonging to the University of Missouri borders the site on the east. The land within a 1 -mile radius of the site boundary has numerous other uses, including being the site of the wildiife area headquarters and a high school.

\subsubsection{Effect of Current Site Activities on the Environment}

The Weldon Spring Chemical Plant is an abandoned Army installation that was used previously for the manufacture of trinitrotoluene (TNT) and dinitrotoluene (DNT) and for the preparation of uranium into $\mathrm{UF}_{6}$ from the beginning stage of yellowcake. The plant has high levels of contamination throughout, and is currently maintained by a caretaker force.

\subsection{CRITERIA FOR ASSESSING THE SITES}

A number of factors were used to assess the relative suitability of the four sites for the placement of a central consolidation facility. These factors were:

1. proximity and accessibility

2. availability of an existing facility

3. resource availability

4. institutional considerations

5. environmental considerations.

The most important consideration was the proximity of each site to other sites that generate LLW and to the currently available disposal sites. This issue is of prime importance for two reasons: first, because the cost of waste transportation increases and the safety decreases with increasing transportation distance; and second, because transportation is an operational 
cost that would continue for years. Proximity to the disposal sites was considered less important than proximity to the waste generators because shipments from the consolidation facility to the disposal sites would be fewer and smaller than those from the waste generators to the facility. Also considered as part of this topic was the accessibility of each site by road, rail, and air.

The availability of a building suitable for use as a consolidation facility was the next most important factor in the site assessment. The availability of storage space capable of housing a year's volume of waste (up to $30,000 \mathrm{ft}^{3}$ of waste in barrels and $5000 \mathrm{ft}^{3}$ of refrigerated waste) was considered as part of this criterion. The modification of an existing and available building would be less costly and less time-consuming than the construction of a new facility. However, either modification or construction would involve only a one-time cost, as opposed to the ongoing cost of waste transportation.

The resources needed to operate a waste consolidation facility would include both staff and equipment. Radiation protection staff, technicians, and support personnel (warehouse workers and clerical staff) would be needed, and backup personnel should be available onsite, including a quality assurance specialist and security and emergency response personnel. The site should also offer backup instrumentation (e.g., calibration support), auxiliary power, and readily available shipping materials and office and laboratory supplies. (See Section 6.0 for a more detailed discussion of these needs.) The availability of these resources was considered less important than the existence of a suitable building because training staff and purchasing equipment would not affect the cost and timing of facility startup as significantly as would constructing or extensively modifying a facility. Training and equipment purchasing could be carried out concurrently with, and completed before or the same time as, readying the facility.

Institutional issues included public sentiment toward current site activities and the probable attitude of both the local public and the site command toward the possibility of a waste consolidation facility being located at the site. These issues are of concern because lack of support could cause 
long delays in the startup of the facility and require an extensive public relations and information program.

Environmental considerations included the following: the susceptibility of each site to natural events that might cut off access to the site, such as flooding or heavy snows, or that might lead to a release of wastes, such as flooding, tornadoes, hurricanes, or heavy rainfall (more than 50 inches per year); the impact that the construction or modification of a facility and its subsequent operation might have on the environment; and the impact of potential operational accidents on the environment.

Regulatory issues were also considered, including applicable federal, state, and local regulations on the packaging, marking, and shipping of hazardous and low-level wastes, waste form requirements for wastes that are to be buried, and the types of provisions that may be imposed by regional compacts for $L L W$ management. The impact of regional compacts on the operation of a consolidation facility is difficult to predict. The impact of federal and state regulations would be similar for all four sites; therefore, this issue was not considered to be a differentiating factor and is not included in the following assessment of the sites. It is discussed separately in Section 8.0 of this report.

\subsection{ASSESSMENT PROCEDURE AND FINDINGS}

The four sites being considered for a consolidation facility were visited by PNL staff. To ensure that each site was assessed using the same criteria, a detailed checklist was developed using questions relating to the five topics just discussed: the proximity and accessibility of the site, the availability of an existing facility, resource availability, institutional considerations, and environmental considerations. The checklist is reproduced in Appendix A. Site documents (e.g., Environmental Impact Assessments) were also reviewed during the site visits. The findings from the assessment of each site are summarized in Table 3.1 and discussed below.

\subsubsection{Proximity and Accessibility}

Waste generators in the vicinity of Aberdeen produce the greatest bulk of Army LLW. Between $80 \%$ and $87 \%$ of the Army LLW generated in the continental 
TABLE 3.1. Summary of Findings from the Review of Four Candidate Sites

Assessment Criteria

Proximity and

Accessibility

Proximity to waste generators

Proximity to buria

sites

Site accessibility

Facility availability and suit-

i

ability

Resource Availability

Institutional

Considerations

Probable public response to

facility

Site command's

response to

facility
Aberdeen

Anniston

Sierra

Weldon Spring

Eastern generators

Southeastern generators

Barnwel1, Beatty the Rocky Mountains

Hanford

Interstate, rail, and air

US 395, rail, and

air

Storage tanks avail-

able, but no building

CSL's Building 2360 would need further

renovation; storage space available

Trained staff readily available; instruments, equipment

and utilities

readily available

Limited trained staff;

limited instruments,

equipment, and util-

ities (electricity

and water)

Building 593 would need some renovation

to serve as satel-

lite facility

Trained staff available; instruments

and equipment available; utilities somewhat limited but

available

Neutral

Would require some PR in St. Louis

Favorable
Generators east of the Rocky Mountains

Central to available burial sites

State highway, rail, and air

Building 408 would need extensive modifications; has storage areas

No trained staff; no instruments or equipment; utilities limited
Neutral 
TABLE 3.1. (contd)

\begin{tabular}{|c|c|c|c|c|}
\hline Assessment Criteria & Aberdeen & Anniston & Sierra & Weldon Spring \\
\hline $\begin{array}{l}\text { Environmental } \\
\text { Considerations }\end{array}$ & $\begin{array}{l}\text { Minimal - high } \\
\text { groundwater and } \\
\text { directly on bay }\end{array}$ & Minimal & $\begin{array}{l}\text { May occasionally be } \\
\text { temporarily snow- } \\
\text { bound in winter }\end{array}$ & $\begin{array}{l}\text { Minimal - tornadoes, } \\
\text { area transportation } \\
\text { in winter }\end{array}$ \\
\hline $\begin{array}{l}\text { Suitability for } \\
\text { Central or Satellite } \\
\text { Facility }\end{array}$ & Either & Either & Satellite only & Central only \\
\hline Other Comments & $\begin{array}{l}\text { Edgewood staff in- } \\
\text { terested, Aberdeen } \\
\text { not }\end{array}$ & $\begin{array}{l}\text { Personnel } \\
\text { enthusiastic }\end{array}$ & $\begin{array}{l}\text { Has area for off-hours } \\
\text { truck lockup }\end{array}$ & $\begin{array}{l}\text { Would require exten- } \\
\text { sive refurbishing } \\
\text { and complete } \\
\text { staffing }\end{array}$ \\
\hline
\end{tabular}


U.S. was generated in Washington, D.C., and the state of Maryland in 1979, 1980, and 1981. Therefore, with respect to proximity to waste generators, Aberdeen would be the best location for a central consolidation facility. Should the Army choose to use satellite facilities, neither Anniston nor Weldon Spring would be appropriate because the amount of waste generated in their region of the country (only $4 \%$ in the Southeast and the lower Mississippi region) is not sufficient to justify the expense and operation of a satellite. A satellite facility could be constructed at the Sierra site to handle the LLW from the West Coast, Southwest, and intermountain regions. Only $7 \%$ of the Army's LLW originates in this region; however, the distance from the region to the three other sites under consideration is so great that both safety and cost considerations might make the establishment of a satellite facility at Sierra advisable. Recommended service regions for a central consolidation facility at Aberdeen and a satellite facility at Sierra are shown by the dashed line in Figure 3.1.

The Anniston and Aberdeen sites are relatively close to the Barnwell disposal site (see Figure 3.1). Weldon Spring is located farther away from Barnwell than Aberdeen is. The Sierra site is approximately as close to the Hanford LLW facility as Aberdeen is to Barnwell. However, the issue of proximity to disposal sites is complicated by the way in which the Army disposes of its LLW. Because heavy shipments from Aberdeen fill the Army's waste volume allocation of 396 cubic feet at Barnwe11, and because of the cost of the third-party inspections required at Beatty, most of the Army's other LLW is shipped to Hanford for disposal. Given this current pattern for waste disposal, Sierra would be the preferred site for a consolidation facility, with respect to proximity to a disposal site. (a) of the remaining sites, Anniston would be preferred over Aberdeen because of its proximity to Barnwell, and Aberdeen would be preferred over Weldon Spring because of its proximity to Barnwell and its being the primary generator of the Army's LLW.

(a) When the state of Maryland becomes party to a compact region with operating facilities, Aberdeen will clearly be the preferred location for a consolidation facility because of its proximity to waste generators. However, the course and schedule of the implementation of the compacts and the operation of their LLW disposal facilities cannot be predicted at this time. 
All of the sites have the transportation links that a consolidation facility would need: all are close to federal and/or interstate highways, have adequate rail connections, and are relatively close to commercial or auxiliary airfields (see Table 3.2). However, Sierra is more susceptible than the other sites to road closures due to snowfall, and its occasional inaccessibility during the winter months would delay shipments until the roads were cleared.

\subsubsection{Availability of an Existing Facility}

At each site, a number of buildings were inspected. Discussions were then held with the base commander and the radiation protection officer to determine the availability of the buildings considered as potential facilities by the PNL review team. Anniston does not have a suitable building. Aberdeen and Weldon Spring have buildings, but each would require major work before it could be used as a consolidation facility. Sierra has a building that, with some renovation, could serve as a satellite facility.

Two locations were reviewed at Aberdeen; both locations were in the flood plain within a controlled area that would require an escort for commercial trucks to enter. However, neither had any permanent structures. A third area was then viewed on the Edgewood Arsenal of the Aberdeen Proving Ground. The management of the Chemical Systems Laboratory (CSL), which is located there, recommended that Building 2360 be considered for the primary consolidation facility. This building is currently being renovated by CSL for use as a consolidation facility for its own waste. Associated storage areas are sizable and include a large refrigerator for storing biological radioactive waste (institutional waste). Building 2360 would not be large enough to handle the majority of the Army's LLW without further major renovation. However, the CSL did offer to make its new $\$ 4.2$ million incinerator available when it is not being used to purify chemically contaminated tanks and equipment. Although there are no direct roads to the site, the CSL representative stated that a road could be cut so that trucks would not have to go through two security checks. 
TABLE 3.2. Means of Access to Potential Sites

\begin{tabular}{|c|c|c|c|}
\hline Site & Highways & Railroads & Air \\
\hline Aberdeen & $\begin{array}{l}\text { Access via US } 40, \\
\text { located close to I-95 }\end{array}$ & $\begin{array}{l}\text { Outside service } \\
\text { furnished by Penn- } \\
\text { Central }\end{array}$ & $\begin{array}{l}\text { Baltimore-Washington } \\
\text { Airport is } 14 \text { miles } \\
\text { southwest of Aber- } \\
\text { deen; the site has } \\
\text { two airfields, one } \\
\text { of which can accom- } \\
\text { modate up to the C-5 }\end{array}$ \\
\hline Anniston & $\begin{array}{l}2.1 \text { miles from US } 78 ; \\
4.7 \text { miles from } \mathrm{I}-20\end{array}$ & $\begin{array}{l}\text { Outside service } \\
\text { furnished by } \\
\text { Southern Railroads }\end{array}$ & $\begin{array}{l}\text { Emergency helicopter } \\
\text { site; commercial } \\
\text { service available at } \\
\text { Anniston Municipal } \\
\text { Airport }\end{array}$ \\
\hline Sierra & 7 miles from US 395 & $\begin{array}{l}\text { Two rail roads } \\
\text { provide freight } \\
\text { service }\end{array}$ & $\begin{array}{l}\text { Amellee Army Air } \\
\text { facility, } 7.5 \text { miles } \\
\text { north of the site, } \\
\text { can accommodate C-14] } \\
\text { and proposed C- } 5 A \\
\text { transport }\end{array}$ \\
\hline $\begin{array}{l}\text { Weldon } \\
\text { Spring }\end{array}$ & $\begin{array}{l}\text { Situated on State } \\
\text { Highway } 94 \text {, less } \\
\text { than } 2 \text { miles from } \\
\text { the junction of } \\
94 \text { and US } 42\end{array}$ & $\begin{array}{l}\text { Outside railroad } \\
\text { service adjacent } \\
\text { to site }\end{array}$ & $\begin{array}{l}\text { Commercial service } \\
\text { can be provided by } \\
\text { Spirit of St. Louis } \\
\text { Aviation Airport, } 4 \\
\text { miles east of the } \\
\text { site }\end{array}$ \\
\hline
\end{tabular}

No existing structures at Anniston are now available to serve, or to be modified to serve, as a waste consolidation facility. Two covered storage docks in Area 16 have been used to repackage and store LLW (principally compasses and watches) received from other sites. These storage docks are immediately adjacent to rail tracks and are roughly 100 yards apart. Located elsewhere at the site are large cylindrical metal buildings (tank farms), which are being used for the additional LLW storage of locally generated waste. Members of the Anniston staff suggested that, if a consolidation facility were built there, it should be located in either Area 16 or the tank farm area.

At Sierra, the base commander, the RPO, and other staff agreed that Building 593 would be the best location for a consolidation facility. This 
building has a number of desirable features such as shielded walls, a laboratory counting room, isolated bays with hoists, and a large double door for easy access for trucks. The building is located in a fenced-in area that contains several other buildings, two of which would be good for a storage facility. The major drawback is that Building 593 is too small to serve as the principal consolidation facility. However, the modification of this building would be more economical and faster than the construction of a new facility.

The principal building under consideration at Weldon Spring was Building 408 , which is a large $\left(>50,000-\mathrm{ft}^{2}\right)$ abandoned warehouse. Building 408 is adjacent to the front gate and is easily accessible. It could house the entire waste consolidation operation, as well as handling all of the Army's storage requirements for 2 years. It also has a loading dock, a maintenance shop, several offices, and two cranes. However, it would require other major renovations to be suitable as a consolidation facility.

For more specifics on the renovations needed for available facilities at Aberdeen, Sierra, and Weldon Spring, see Section 4.2.

\subsubsection{Resource Availability}

Both Aberdeen and Sierra have trained personnel to handle emergency and security operations. Aberdeen has the most extensively trained staff, and site requirements could be satisfied with very little impact on other site operations. Neither Anniston nor Weldon Spring has the personnel to handle the monitoring and emergency operations that would be required for a consolidation facility, although it was indicated that Anniston could probably establish a satisfactory working agreement with Fort McClellan (approximately 7 miles away) to use its emergency response team. On the basis of personnel training issues, Aberdeen is the best site and Sierra is satisfactory. Both Anniston and Weldon Spring would need to develop and implement detailed training programs.

Much of the necessary instrumentation and equipment is available at the Aberdeen and Sierra sites. Aberdeen has better laboratory space and assay instrumentation than the other sites. Only limited instrumentation is 
available at Anniston, and essentially none of the instrumentation or equipment needed is available at Weldon Spring. The availability of supplies and materials should not be a problem for any of the sites. The necessary utilities are available at the Aberdeen and Sierra sites. There are limited utilities at Weldon Spring, but at this time it is not possible to determine whether they could be put back in service. The utilities at Anniston would need to be added to by extending existing lines and piping. The availability of utilities (gas, electricity, and water) is of primary importance because it is quite costly to have to add them.

\subsubsection{Institutional Considerations}

Information gathered from site personnel during the visits to the four sites indicated that, except at Weldon Spring, the nearby citizens generally support the sites' current activities and would not be expected to oppose the proposed facility. Cognizant Army personnel from both Sierra and Anniston appeared highly interested in having the operation located at their site. At Aberdeen, support for the operation was somewhat less apparent than at other sites; however, the staff were very supportive of the consolidation concept. It appeared that the multiple commands at Aberdeen could tend to delay actions. Benefit to the locality would likely be greatest at Weldon Spring because the facility would afford the Army the opportunity to at least partially clean up and dispose of waste from previous activities. However, in the absence of such a commitment by the Army, the public is expected to oppose the operation at Weldon Spring. Based on the site visits, Sierra and Anniston showed the greatest interest and support. This support, combined with the fact that Sierra is a very remote site, tends to make Sierra slightly preferred over Anniston on this issue.

\subsubsection{Environmenta] Considerations}

All of the sites except Sierra are susceptible to flooding, tornadoes, hurricanes, or heavy rainfall (more than $50 \mathrm{in./yr}$ ). However, with the exception of heavy rainfall, the probability of these events happening is very low and would not be a controlling consideration in the final selection. As 
already mentioned, some of the sites are susceptible to winter transportation problems caused by heavy snow, particularly the Sierra site.

The environmental impacts associated with the construction and operation of a central waste consolidation facility or a satellite would be nominal. Construction impacts would be routine and would have no negative effect on the surrounding environment. Regulatory requirements would limit exposures and normal releases to levels determined to be acceptable and not environmentally significant. Operational accidents could potentially lead to exposures or releases that exceeded acceptable limits for a short time, but the impacts would be local, with only short-term effects on the surrounding environment. If a natural event (i.e., tornado, hurricane) occurred that was severe enough to release to the environment the wastes stored at the facility, it would also disrupt other depot activities, which would probably result in more significant impacts than those associated with the waste-handling facility.

\subsection{SUMMARY ASSESSMENT OF CANDIDATE SITES}

For the purpose of evaluating the relative merits of the four sites as a suitable location for a consolidation facility, the assessment criteria were assigned weighting factors according to their relative significance (see Table 3.3). For example, the proximity of a site to other LLW generators, the most important factor, was given a weighing of 5 . Because the environmental considerations were similar at all sites and therefore of least importance in distinguishing among the sites, this criterion received a weighting factor of 0 .

The four sites were then ranked for each of the assessment criteria, based on the findings from the site visits and the review of site documents, to indicate which site was preferred and which was least desirable. The rankings were assigned using numerical values, with 4 for the preferred site and 1 for the least desirable. The weighting factor for each assessment criterion was then multiplied by the site's ranking on that criterion to give a weighted value (see Table 3.3 ).

The sum of the weighted numerical values for each site provides a measure of that site's suitability for housing a central consolidation facility. As 
shown in Table 3.3, the preferred site for the central facility is the Aberdeen Proving Ground. The Sierra Army Depot, which is second in the overall ranking, would be suitable for a satellite facility if the expense of the necessary modifications can be justified. 
TABLE 3.3. Site Ranking for a Central Consolidation Facility

\begin{tabular}{|c|c|c|c|c|c|c|c|c|c|}
\hline \multirow[b]{2}{*}{ Assessment Criteria } & \multirow{2}{*}{$\begin{array}{l}\text { Criteria } \\
\text { Weighting } \\
\text { Factors } \\
\end{array}$} & \multicolumn{2}{|c|}{ Aberdeen } & \multicolumn{2}{|c|}{ Anniston } & \multicolumn{2}{|c|}{ Sierra } & \multicolumn{2}{|c|}{ Weldon Spring } \\
\hline & & Rank $^{(b)}$ & Value & Rank $^{(b)}$ & Value & $\underline{R a n k}^{(b)}$ & Value & $\underline{\operatorname{Rank}}^{(b)}$ & Value \\
\hline $\begin{array}{l}\text { Proximity to } \\
\text { generators of LLW }\end{array}$ & 5 & 4 & 20 & 3 & 15 & 1 & 5 & 2 & 10 \\
\hline $\begin{array}{l}\text { Proximity to } \\
\text { disposal sites }\end{array}$ & 4 & 2 & 8 & 3 & 12 & 4 & 16 & 1 & 4 \\
\hline $\begin{array}{l}\text { Facility } \\
\text { availability }\end{array}$ & 3 & 3 & 9 & 1 & 3 & 4 & 12 & 2 & 6 \\
\hline $\begin{array}{l}\text { Resource availabil- } \\
\text { ity (trained staff } \\
\text { and equipment) }\end{array}$ & 2 & 4 & 8 & 2 & 4 & 3 & 6 & 1 & 2 \\
\hline $\begin{array}{l}\text { Institutional } \\
\text { considerations }\end{array}$ & 1 & 2 & 2 & 3 & 3 & 4 & 4 & 1 & 1 \\
\hline $\begin{array}{l}\text { Environmental } \\
\text { considerations }\end{array}$ & 0 & ND & ㅍ- & ND & - & ND & $=$ & ND & ㅍ \\
\hline $\begin{array}{l}\text { Sum of weighted } \\
\text { values }\end{array}$ & & & 47 & & 37 & & 43 & & 23 \\
\hline $\begin{array}{l}\text { (a) Criteria Weighti } \\
\text { least heavily we } \\
\text { criterion was ju } \\
\text { (b) Ranking } \\
4=\text { best among s } \\
3=\text { favorable } \\
2=\text { acceptable } \\
1=\text { not preferr } \\
\text { ND }=\text { no differen }\end{array}$ & $\begin{array}{l}\text { Factors: } \\
\text { hted factor. } \\
\text { ed to be of } \\
\text { es }\end{array}$ & $\begin{array}{l}\text { indicates } \\
\text { Environn } \\
\text { ittle val }\end{array}$ & $\begin{array}{l}\text { the mos } \\
\text { ntal co } \\
\text { e in di }\end{array}$ & $\begin{array}{l}\text { heavily v } \\
\text { ideration } \\
\text { inguishir }\end{array}$ & $\begin{array}{l}\text { eighted } \\
\text { s has a } \\
\text { among }\end{array}$ & $\begin{array}{l}\text { (most impor } \\
\text { weighting } f \\
\text { the sites. }\end{array}$ & $\begin{array}{l}\text { tant) } \mathrm{fac} \\
\text { actor of }\end{array}$ & $\begin{array}{l}\text { or and } 1 \\
\text { because }\end{array}$ & $\begin{array}{l}\text { the } \\
\text { this }\end{array}$ \\
\hline
\end{tabular}




\subsection{FUNCTIONAL DESIGN CRITERIA}

In this section, a design for a waste consolidation facility is proposed. The design requirements that such a facility would have to meet are identified, and design features are described. In addition, the required modifications of available facilities at Aberdeen, Sierra, and Weldon Spring are described.

\subsection{PROPOSED DESIGN FOR A WASTE CONSOLIDATION FACILITY}

A proposed design for a waste consolidation facility is depicted in Figure 4.1. The facility has enclosed areas to permit the safe receipt, inspection, identification, and segregation of incoming waste containers. The waste would be segregated according to the volume reduction methods to be used, such as incineration or compaction (see Section 5.0). Specific areas for carrying out the various volume reduction methods would be designed to minimize exposure, ensure operator safety, and prevent the release or dispersion of radioactive particulate matter. The facility design shown in Figure 4.1 provides for a packaging and storage area for the reduced volume prior to its final end-point shipment. An enclosed loading dock for the transport vehicle is also provided adjacent to the final storage area.

Required support spaces include facilities for radiation monitoring, records storage, personnel decontamination, computers, shielded low-level counting, restrooms and change rooms, offices, and the facility's mechanical equipment. The facility should be located in an area with an elevation above the 100-year flood level. Access routes for the vehicles transporting the incoming and outgoing wastes must be provided, as well as methods of restricting and regulating access to the facility.

\subsubsection{General Requirements}

The latest editions of the following codes, standards, executive orders, and congressional acts apply to the design and construction of the proposed LLW consolidation facility. 


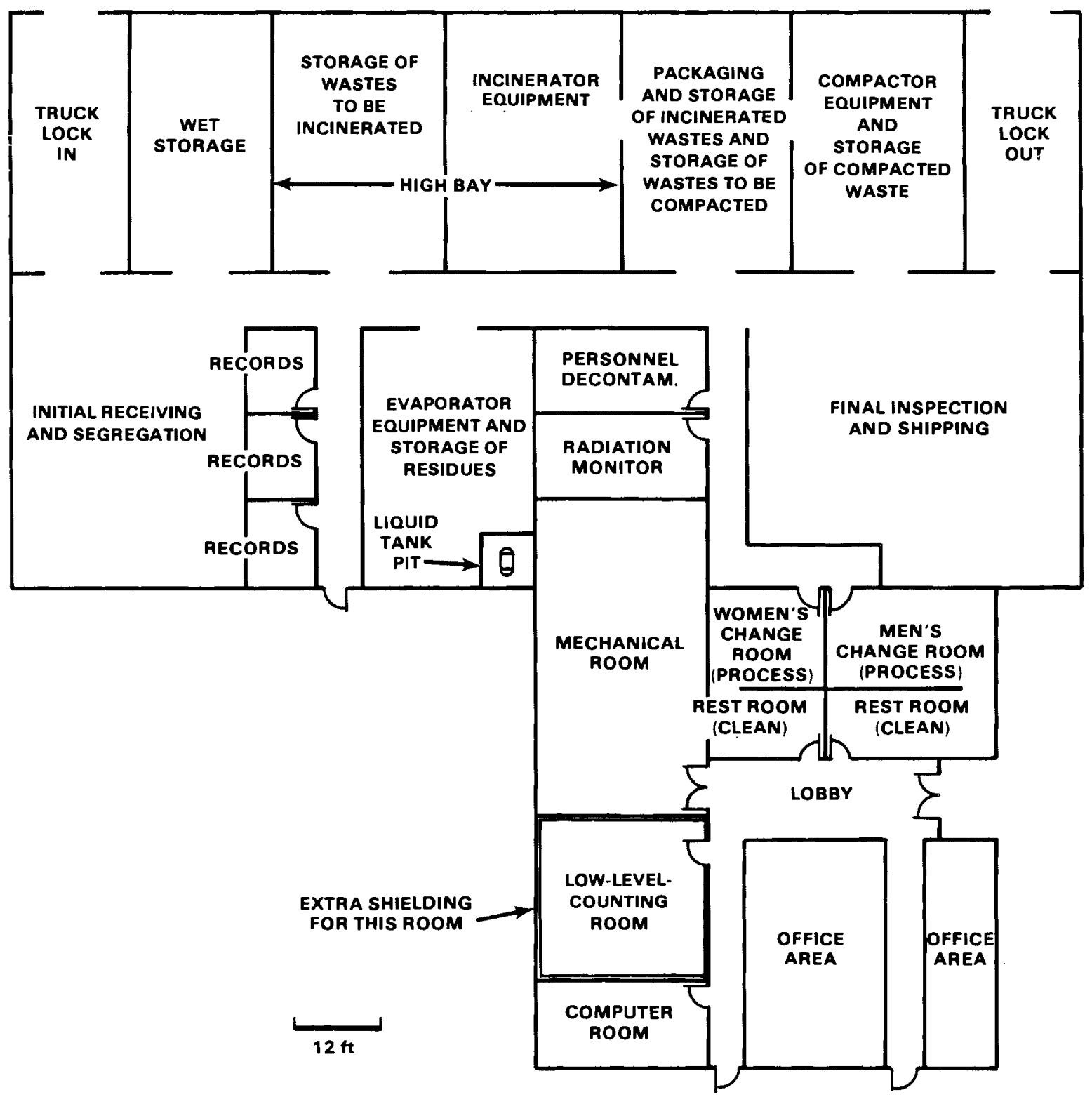

FIGURE 4.1. Proposed Design for a Radioactive-Waste Consolidation Facility 
- National Environmental Policy Act of 1969, as amended

- Executive Order 11988, "Flood Plain Management"

- Public Law 91-596, Occupational Safety and Health Act of 1970

- Seismic Design for Buildings, TM 5-809-10, U.S. Department of the Army

- Uniform Building Code (UBC)

- National Fire Code (NFC-NFPA)

- Uniform Pluming Code (UPC)

- National Electric Code (NEC)

- American Water Works Association (AWWA)

- American Concrete Institute (ACI)

- American Welding Society (AWS)

- other local, state and federal codes and standards as applicable to the site

- weather data

- Air Force Manual 88-8, Chapter 6, "Engineering Weather Data"

- American Society of Heating, Refrigeration and Air Conditioning Engineers (ASHRAE)

- high-efficiency particulate air (HEPA) filters

- Energy Research and Development Administration (ERDA) 76-21, "Design, Construction and Testing of High Efficiency Air Cleaning Systems for Nuclear Application"

- American National Standards Institute (ANSI) Standards - HEPA Filter Testing, ANSI-510; Air Sampling, ANSI N13; Efficiency Testing of Air Cleaning Devices, ANSI-N-101

- Underwriter Laboratories (UL) UL-586

\subsubsection{Functional Requirements}

The facility shall meet or exceed all of the above-referenced codes. Due to the potential for radioactive contamination, all interior surfaces of the facility process section should be able to be decontaminated in the event of periodic or accidental releases of radioactive materials within the facility. For example, if the floor is concrete, it should be covered with a durable, nonporous material that can be decontaminated. The design should also include consideration of the potential future decontamination and decommissioning of the entire facility. 
A curb of sufficient height to contain any leakage from the stored liquids or the volume of water from an operating fire sprinkler should enclose the process area. Entries should be ramped. Adequate shielding should be provided around designated areas to reduce exposures of plant personnel to levels that are as low as is reasonably achievable (ALARA). The ventilation and piping systems should be located above a suspended ceiling to reduce the cleanup (decontamination) problems in the event of an accidental release of radioactivity. The minimum ceiling height should be 9 feet in the process areas of the facility. A high bay will be necessary for the incinerator area and may be reasonable for the storage areas. The facility should be designed and constructed to be energy efficient and should be constructed of noncombustible materials.

\subsubsection{Architectural-Structural Considerations}

The proposed facility is divided into two sections: an office and support area, and a process area.

The office and support area would be designated for nonradioactive work and should be similar to office areas in industrial buildings. This area should be designed in accordance with the reference codes. Space requirements for the office area include:

- four to six office spaces for the administrative staff - the offices should be large enough to accommodate a manager, a secretary or other operating personnel, and typical office equipment and furnishings

- a computer room for computer maintenance of facility records - size will be determined by the type of computer selected for the facility

- storage spaces for clothing, packaging materials, office supplies, and other related items

- a shielded low-level counting room with specially constructed walls and other structural features to minimize radiation background levels from the other areas within the facility.

- a mechanical/electrical room to contain all facility mechanical and electrical equipment, with access from the office section. 
The process area would be designated for the radioactive work. Operating personnel must enter. and leave this area via a change room. Space requirements for the process area of the building include:

- a compactor room and storage area to house the waste compactor and materials to be processed

- a personnel decontamination room for the radioactive decontamination of operating personnel in the event of accidental exposure

- a radiation-monitoring office and equipment room to house the radiation-monitoring personnel and the necessary radiation-monitoring equipment

- records and receiving offices near the truck-loading dock, for personnel who receive, inspect, and place the necessary tracking information on the incoming material - the records will be stored in this space until information is transferred to the computerized recordkeeping system

- a storage area for the inspection, identification, and segregation of incoming waste, and the storage of the segregated materials

- an incineration room and storage area - a high bay would be needed to accommodate the incinerator and auxiliary equipment

- a liquid waste treatment room to house the ion exchange, reverse osmosis, evaporation, or other volume reduction equipment

- a storage area for outgoing materials, to provide space for packaging, inspection, storage, and final monitoring of all outgoing materials.

\subsubsection{Mechanical Design Features}

A separate heating, ventilation and air conditioning (HVAC) system should be provided for the office and support area. The HVAC for the process area should be provided from a main system located outside the process area, with conditioned air distributed by ductwork to the individual process spaces. The ductwork should be located above the ceiling of the process area. The ventilation system should provide four to eight air changes per hour and should be one-pass with no air recirculation. Medium-efficiency air supply 
filters should be provided. The heating medium (steam, heat pump, electricity or gas) should be determined based on economics and availability at the site selected.

Cooling should be provided by a mechanical refrigeration system. The installation of heat recovery coils for extracting energy from the exhaust system should be considered and evaluated based on life-cycle cost comparisons. Humidity control is not critical.

The exhaust system for the process area should consist of collection ductwork, medium-efficiency prefilters upstream from the HEPA filters, an exhaust fan, and an exhaust stack. Provision should be made for isokinetic sampling of the exhaust stack. The process area should be maintained at a negative pressure to the office section and to the outside ambient conditions. The exhaust volumes could be maintained by velocity pressure controllers in the exhaust stack, with signals to the vortex dampers at the exhaust fan intake. These controllers would automatically compensate for the pressure buildup due to particulate loading of the exhaust filters. The system's operation sequence should require that the exhaust fan be operating before the supply system can be activated. Upon loss of exhaust from the process area, the supply system should be deactivated.

Isolating dampers upstream from the exhaust fan should operate automatical1y. In a de-energized condition, the damper should be closed; during operation, the damper should be fully open. Upon loss of normal power to the facility, the damper on the exhaust system should fail closed. The supply fan inlet damper should close when normal power is lost. The supply fan vortex damper should be controlled to a set pressure downstream from the filters and coils, to automatically compensate for dirt loading of the supply-side air filters.

After initial installation, the systems should be balanced by a qualified air-balance contractor. Ventilation system acceptance tests should be prepared to ensure operation in accordance with the functional requirements. Requirements for the piping systems include: 
- water (sanitary) - Hot and cold sanitary water should be provided for the change room/restroom facilities; drinking water should be provided in the office area.

- water (process) - Water required for the process area should be equipped with a reduced-pressure-principle back-flow preventor.

- water (decontamination facility) - Any water required for the personnel decontamination facility should be sanitary water and should be protected at the use point by approved vacuum breakers.

- gas (propane, natural gas, etc.) - Any gas supplied for the incineration process should be piped in accordance with ANSI B31.1.

- vacuum air-sampling system - A vacuum air-sampling (VAS) pump and collection piping should provide for one air-sampling head in each of the process areas, located at approximately the personnel breathing-zone elevation. Each air-sampling point should be capable of extracting 1-1/2 to $3 \mathrm{cfm}$ of air over the VAS filter media. In addition to samples from these zones, a sample should be extracted from the exhaust system stack to verify the exhaust air quality.

- waste piping systems - The sanitary system waste piping should conform to the Uniform Plumbing Code. The process waste piping systems should be designed to contain all process liquids for retention and sampling prior to final disposal. In the personnel decontamination facility, a holding tank should be employed to collect all of the decontamination liquid. Provisions should be made to extract a liquid sample prior to disposal of the decontamination liquid. If the quality of the liquid is within allowable limits for discharge to the sanitary sewer system, a pump should dispose of the accumulated liquid. If the liquid concentration is above allowable discharge concentrations, the liquid should be pumped overhead to a collection tank located within a concrete pit equipped with a stainless-steel liner to prevent leakage to the environment. The storage area for liquids accumulated prior to volume reduction should be equipped to contain liquid spills. 
- fire protection - The entire facility should be provided with a wet-pipe sprinkler system based on ordinary hazard occupancy, in accordance with NFPA requirements.

\subsubsection{Electrical System}

The following conditions apply to the electrical system:

- power - Three-phase, four-wire power at 480/277 volt (V) $60 \mathrm{Hertz}(\mathrm{Hz})$ should be provided for the facility. Three-phase, 480-V power should be provided for the HVAC system and for the volume reduction equipment. Three-phase 208Y/120-V dry-type transformers and circuit breaker panelboards should be provided for single-phase loads and duplex grounding outlets.

- computer facility - A three-phase isolated power supply from the 480-V switchgear should be provided for the computer facility and low-level counting room. For the computer room, a three-phase transformer with $480-V$ primary and $280 \mathrm{Y} / 120-V$ secondary should be provided. An electrostatic shield between primary and secondary should also be provided. A main-line contractor for the computer facility panelboard should interrupt power if smoke detectors in the computer room operate, if a high temperature is detected, or if a manual switch is operated. An isolated ground conductor should be provided for the computer transformer.

- lighting - Fluorescent lighting fixtures with 277-V ballasts should provide a maintained illumination level of 70 foot-candles in the process areas. Lighting levels in office and auxiliary spaces should be as specified in the Illuminating Engineering Society Handbook and should be supplied by fluorescent fixtures with $277-V$ ballasts. Emergency lighting should be provided by individual unit equipment with rechargeable battery, dual-rate charger, two lamps, and transfer relays to energize lamps automatically when normal lighting fails.

\subsection{RENOVATION AND REDESIGN OF EXISTING FACILITIES}

The site evaluations included a review of buildings that might be 
available for and capable of housing the proposed consolidation facility. At three of the four sites, every structure considered would require some renovation or major redesign as discussed below. Anniston, which had no satisfactory buildings and would require all new construction, is not considered here.

\subsubsection{Aberdeen}

Building 2360, located at the Edgewood Arsenal, is currently being renovated to be used as a radwaste consolidation facility for the volume of waste generated at the CSL. Associated with this facility are two storage buildings and one refrigerated storage locker. These buildings were suggested by the CSL as a potential Army consolidation facility. The facility would require major redesigning to accommodate the magnitude of the Army's total radwaste. Nevertheless, this redesign would be considerably less expensive than the efforts required to renovate the existing building at Weldon Spring or construct a new one at Anniston.

\subsubsection{Sierra}

At the Sierra Army Depot, Building 593 could be used to house a satellite consolidation facility. This building already has a shielded counting room, as well as office and restroom facilities. However, a number of changes and additions would be required. The fume hoods currently in the building are not adequate to handle the packaging and repackaging operation. It would also be necessary to design an air exchange system that would vent the building through a HEPA filter, to remove radioactive particulates from the air. This system should create a negative air flow into the building.

A decontamination area would need to be built onto the south side of the building (the north side would be used for storage). This area would be adjacent to a new change room where radiation workers would enter and leave the building. A covered area on the front of the building would be necessary to allow movement of barrels from the work area to the storage area on the north side. A health physicist would be required to assist the design engineer in specifying modification requirements before construction could begin. 


\subsubsection{Weldon Spring}

The only structure at Weldon Spring suitable for the consolidation facility is Building 408, a large (more than 50,000- $\mathrm{ft}^{2}$ ) building formerly used as a warehouse and maintenance shop. This structure would require a new roof. One room is reported to contain $50 \mathrm{lb}$ of uranium contamination and would require decontamination. This is expected to be accomplished by the Army in 1983 for environmental reasons. Once this is accomplished, a design similar to the one described in Section 4.1 would have to be modified to fit Building 408's very high ceiling (over 30 feet) and few partitions. Whole rooms would need to be constructed to retain any possible releases during norma 1 and accident conditions. 


\subsection{VOLUME REDUCTION METHODS}

Volume reduction is the name given to techniques that remove water, air, and combustible organics from radioactive waste to reduce the volume of waste requiring ultimate disposal. Volume reduction techniques can be generally categorized as compaction, crystallization, dehydration, and incineration. These processes, including pretreatment methods, are described in this section. Solidification, also a part of many volume reduction processes, is discussed briefly as well. Volume reduction systems currently available are summarized in Table 5.1, and the requirements of an Army waste consolidation facility are considered at the end of the section.

\subsection{PRETREATMENT}

The first step in the pretreatment of radioactive waste is sorting the waste according to the volume reduction method to be used. Dry active waste (DAW) can be incinerated along with scintillation fluids and other organic waste. Aqueous liquids are most easily handled in a dryer. Material that is not combustible or would exceed effluent release limits if incinerated may be compactible. Waste is also sorted to check for explosive or pyrphoric agents that would present a hazard if processed.

Another step in pretreatment can be the shredding of some wastes. Shredding has been shown to increase the overall volume reduction factor of compaction as well as making feed operations more simple. The combustion of waste in an incinerator also occurs more quickly and uniformly if the waste has been shredded. The two main types of shredders are knife cutters and hammermills. Shred Pax Corporation offers a unique, high-torque, low-speed shredding mechanism that uses knives to tear objects apart with a smooth shearing action. Depending on the shredding model used, such things as metal cans, glass, metal turnings, tires, concrete blocks, and even railroad crosstie butts can be shredded. Shred Pax Model AX-15, which handles pieces of metal less than $1 / 4$ inch in thickness, sells for $\$ 43,000$. A Jacobson Model J-3 hammermill uses rotating hammers to pound waste against a plate. Hammers 
TABLE 5.1. Volume Reduction Systems

\begin{tabular}{|c|c|c|c|c|c|c|}
\hline Supplier & Type & Liq. & Res. & Dry & Solidification & Demonstration \\
\hline \multirow[t]{2}{*}{ ATI (SGN) } & $\begin{array}{l}\text { Thin-film } \\
\text { evaporator/ } \\
\text { dryer }\end{array}$ & $x$ & $x$ & & Bitumen & $\begin{array}{l}\text { Tsurga, Japan } \\
\text { Barseback, Sweden }\end{array}$ \\
\hline & Incinerator & & & $x$ & Bitumen & Los Alamos design \\
\hline AEROJET (a ) & $\begin{array}{l}\text { Dryer/incin- } \\
\text { erator }\end{array}$ & $x$ & $x$ & $x$ & Separate system & Full-scale prototype \\
\hline \multirow[t]{2}{*}{$\begin{array}{l}\text { ATCOR/BELGONU }(a) \\
\text { KRAFTENLAGEN }\end{array}$} & $\begin{array}{l}\text { Evaporator } \\
\text { blender }\end{array}$ & $x$ & $x$ & & Bitumen & $\begin{array}{l}\text { Mol, Belgium, and } \\
\text { Tihange plant }\end{array}$ \\
\hline & Incinerator & & & $x$ & & Julich design \\
\hline $\begin{array}{l}\text { Combustion } \\
\text { Engineering }\end{array}$ & Incinerator & $x$ & $x$ & $x$ & Pelletizer & $\begin{array}{l}\text { Full-scale protype, } \\
\text { wind CO }\end{array}$ \\
\hline General Electric & Inert carrier & $x$ & $x$ & & $\begin{array}{l}\text { Epoxy resin } \\
\text { (thermoplastic) }\end{array}$ & \\
\hline $\begin{array}{l}\text { United Tech. } \\
\text { Corp. }\end{array}$ & Incinerator & & & $x$ & & Rocky Flats \\
\hline \multirow[t]{2}{*}{ Hitachi } & $\begin{array}{l}\text { Wiped-film } \\
\text { evaporator }\end{array}$ & $x$ & $x$ & & Pelletizer & Japan \\
\hline & Incinerator & & & $x$ & & Japan \\
\hline$H P D$, Inc. & $\begin{array}{l}\text { Evaporator/ } \\
\text { crystallizer }\end{array}$ & $x$ & & & Separate system & $\begin{array}{l}\text { Pilot plant - Nine Mile } \\
\text { Point Reactor }\end{array}$ \\
\hline JGC Corp. & Drum mixer & $x$ & $x$ & & Bitumen & \\
\hline
\end{tabular}

(a) Topical reports on file at NRC (for reference in FSAR). 
TABLE 5.1. Volume Reduction Systems (Contd)

\begin{tabular}{|c|c|c|c|c|c|c|}
\hline Supplier & Type & Liq. & Res. & Dry & Solidification & Demonstration \\
\hline Karlsruhe (NGK) & Incinerator & & & $x$ & Separate system & 25,000 hours \\
\hline Koch Process & Incinerator & & & $x$ & Separate system & Los Alamos design \\
\hline Newport News & $\begin{array}{l}\text { Calciner/ } \\
\text { incinerator }\end{array}$ & $x$ & $x$ & $x$ & Pelletizer & $\begin{array}{l}\text { Pilot plant - } \\
\text { Idaho Falls }\end{array}$ \\
\hline Penberthy & Pyro-converter & $x$ & $x$ & $x$ & Glass & Pilot plant - Seattle \\
\hline $\begin{array}{l}\text { Teledyne Energy } \\
\text { Systems }\end{array}$ & Blender/dryer & $x$ & $x$ & & Several agents & \\
\hline TRECAN & Incinerator & & & $x$ & Separate system & Ontario Hydro-Bruce \\
\hline Transnuclear & Incinerator & & & $x$ & Separate system & Karlsruhe design \\
\hline $\begin{array}{l}\text { Werner \& } \\
\text { Pfleiderer (a) }\end{array}$ & $\begin{array}{l}\text { Extruder/ } \\
\text { evaporator }\end{array}$ & $x$ & $x$ & & Bitumen & Marcoule - France \\
\hline Westinghouse & Crystallizer & $x$ & $x$ & & Cement & \\
\hline $\begin{array}{l}\text { UNC Nuclear Ind., } \\
\text { Inc. }\end{array}$ & Dryer & $x$ & $x$ & & Polymer & Pilot plant - Richland \\
\hline $\begin{array}{l}\text { DOW Chemiç̧ } 1 \\
\text { Company }\end{array}$ & Solidification & & & & Polymer & \\
\hline Chem-Nuclear & Solidification & & & & Cement & \\
\hline $\begin{array}{l}\text { Hittman N.S. Dev. } \\
\text { Co. }\end{array}$ & $\begin{array}{l}\text { Evaporator/ } \\
\text { crystallizer/ } \\
\text { incinerator }\end{array}$ & & & & $\begin{array}{l}\text { Cement/sodium } \\
\text { silicate }\end{array}$ & Los Alamos Experiment \\
\hline
\end{tabular}

(a) Topical reports on file at NRC (for reference in FSAR). 
TABLE 5.1. Volume Reduction Systems (Contd)

\begin{tabular}{|c|c|c|c|c|c|c|}
\hline Supplier & Type & Liq. & Res. & Dry & Solidification & Demonstration \\
\hline Stock Equip. Co. & Solidification & & & & & Ontario Hydro-Bruce \\
\hline $\begin{array}{l}\text { UNC Nuclear Ind. } \\
\text { Inc. }\end{array}$ & $\begin{array}{l}\text { Dry-waste } \\
\text { solidification }\end{array}$ & & & & Cement & \\
\hline Waste Technology & Incinerator & & & $x$ & $\begin{array}{l}\text { Cement/sodium } \\
\text { silicate }\end{array}$ & \\
\hline
\end{tabular}


may be rectangular or chisel-shaped and can be mounted on a vertical or horizontal shaft or rotor.

Short-term storage can be a worthwhile pretreatment step for radioactive waste that contains only short-lived radionuclides (half-lives less than 30 days). Usually the material must be stored for 10 half-lives or longer. It can then sometimes be disposed of by conventional methods if the radionuclide concentrations do not exceed the limits set by 10 CFR 20.303 for release into sanitary sewage systems and 10 CFR 20.304 for disposal by burial in soil. Scintillation fluid and animal tissue, for example, may be disposed of as normal waste if their concentrations of hydrogen-3 and carbon-14 are $0.05 \mu \mathrm{C} i$ or less per gram of medium used for liquid scintillation counting and $0.05 \mu \mathrm{C} i$ or less per gram of animal tissue averaged over the weight of the entire anima 1.

\subsection{COMPACTION}

The compaction process mechanically reduces the volume of contaminated trash by bailing or compacting it into drums. Contaminated trash, sometimes considered to be DAW, includes cardboard, paper, gloves, and plastics. Compactor size and power requirements are determined by the throughput, largest feed item, disposal container, volume reduction desired, and material to be compressed. Commercially available compactors differ widely in terms of final densities achievable; however, assuming a raw trash density of $61 \mathrm{~b} / \mathrm{ft}^{3}$, the end product density can be expected to range from 18 to $42 \mathrm{lb} / \mathrm{ft}^{3}$.

The most common compactor used in the industry is the 55-gallon drum compactor. The equipment consists of a hydraulic or mechanical drive, ram, baseplate, structural supports, control panel, and safety enclosure with hood, filter, and fan. Volume reduction factors of two to six have been reported, but can be increased by pretreating the waste (e.g., shredding). Typical costs range from $\$ 15,000$ to $\$ 75,000$.

The Stock Equipment Co. (SECO) Dry Waste Hydraulic Compactor is capable of exerting 30,000 pounds of force with a 7-inch-diameter piston. The clearances above the drum allow for compacting a full 60-inch column of waste into a 55-gallon drum; after each compaction, more waste can be added unti 1 the drum is fu11. The unit is designed to have a 40-year service life with 
minimum maintenance and currently has a price of $\$ 75,000$. The self-contained fan and air filtration system enhance operator safety and remove possible airborne particulates. A SECO dry waste compactor is in operation at the waste volume reduction facility at the Bruce Nuclear Power Development site in Canada. Consolidated Baling Machine Co. and Nuclear Packaging, Inc. also offer compactors for use with standard 55-gallon drums.

Stock Equipment Co. offers complete systems for handling and solidifying low-level radioactive waste. A dry-waste drumming system provides a process for immobilizing and packaging volume-reduced, dry radioactive salts and ash within a polymer matrix. A cement-drumming station is provided for packaging and solidifying concentrated liquid and slurry wastes. Stock Equipment Co. also offers system interfacing with volume reduction processes, storage and transfer equipment for solidification agents, and remotely operated materialhandling equipment.

\subsection{CRYSTALLIZATION}

Crystallization removes much of the water from liquid wastes, usually by evaporation. The end product is a slurry of solids mixed with a saturated solution. The radwaste crystallizer is essentially a specially designed, forced-circulation evaporator consisting of a vapor body, recirculation pipes, recirculation pump, and a heater or heat exchanger. The liquid waste is heated as it passes through the heater or heat exchanger and releases water vapor when it reaches the vapor body. The whole system is designed to handle the undissolved solids that circulate throughout the unit and build up as the liquid is concentrated. Often the crystallization process is used as a form of pretreatment for concentrating liquids that will be further dried in another step.

HPD Incorporated is one supplier of radwaste crystallizers; their equipment is representative of what is available. Tests at their pilot plant performed with SECO have demonstrated the compatibility of the crystallizer with an in-drum-mixing cement solidification system. They have achieved a loading equivalent to approximately 250 pounds of dry salt per drum. HPD's evaporator/crystallizer has also been operated at the Nine Mile Point Nuclear Power Plant. 
Ecodyne Unitech Division offers several varieties of radwaste crystallizers/evaporators. These include the vertical-tube falling-film evaporator, the horizontal-tube forced-circulation evaporator, and the vertical-tube forced-circulation evaporator. These crystallization systems can concentrate low-level liquid waste to over $50 \%$ by weight of solids and have been supplied since 1972 .

Hittman Nuclear and Development Corporation (HNDC), now a subsidiary of Westinghouse Electric Corp., offers a volume reduction and solidification system for liquid radioactive waste. Their equipment consists of a thin-film evaporator working as a crystallizer, coupled with a high-shear mixer, which is part of HNDC's standard cement solidification system. The specific mixes of water, cement, and additives are proprietary in nature, although packaging efficiencies are said to range from $60 \%$ to $70 \%$ for 1 iquids. They also provide other ancillary equipment required for a complete waste processing facility.

\subsection{DEHYDRATION}

Dehydration removes all the water from aqueous liquid wastes, leaving a dry residue. Calcination is also a dehydration process but will be treated under incineration because it drives off other volatile oxides as well as water.

Teledyne-Readco markets a volume reduction system that uses a blender/ evaporator as a dryer. The blender/evaporator is a ribbon blender with a steam jacket. The evaporator concentrate or slurry is mixed until all the water is evaporated. The dry product is then transferred to a Readco mixer along with any one of several solidification agents. To date, Teledyne has operated a pilot plant version of this system.

ATCOR, a Chem-Nuclear Company, is the U.S. outlet for a liquid radwaste system produced by Belgonucleaire of Belgium. The volume reduction and solidification system is based on a development program conducted by ATCOR/ Belgonucleaire at their full-scale pilot plant in Mol, Belgium. Evaporation of the water in the liquid waste and incorporation of the binder are achieved together in a single-stage process using an intensive dryer/mixer. A thinfilm evaporator preceding the intensive dryer/mixer is an available process 
option. The dryer/mixer is a jacketed horizontal container with co-rotating shafts and impellers for mixing and heat transfer. Liquid waste is fed in at a rate of 0.5 to $3 \mathrm{gpm}$. The end product can be dry granular solids or a paste incorporated into a solidification matrix. The unit may be operated as a dryer, a cooler, or a high-shear mixer, or as a combination of all three when appropriately zoned. Pretreatment using ATCOR's proprietary chemical treatment process is required to produce a waste form that does not glass or slag during dehydration or crystallize during storage or transfer. The system is totally compatible with cement, polymer, and other solidification matrices and results in an end product with excellent long-term strength characteristics. Operating experience at the Tihange Plant near Liege, Belgium, has demonstrated volume reduction factors between 11 and 12 for borates solidified in cement and 9.7 for sulfates in cement. The dryer/mixer with solidification sells for about $\$ 2$ million.

Through Associated Technologies Incorporated (ATI), SGN of France is marketing a volume reduction process. The SGN volume reduction process combines the two operations of drying and solidifying liquid waste. The evaporation and mixing take place in a LUWA-thin-film evaporator; the solidification agent is straight distilled bitumen, which is solid at room temperature. The bitumen is electrically heated to maintain fluidity. Waste and molten bitumen are fed into the top of the vertical evaporator where motor-driven rotor blades spread a thin film of both on the heated interior surface. The bitumen and waste are mixed by the blades and the water is evaporated before the mixture emerges from the bottom. The mixture is deposited in the disposal container and solidification occurs as the bitumen cools. Heat is supplied to the evaporator by circulating a heated organic fluid through an outer jacket. The organic fluid is used instead of steam because the high pressure of the steam would require more expensive construction of the evaporator. This system is the same as the SGN systems currently in use at Tsuruga, Japan, and Barseback, Sweden. The system is capable of removing $99 \%$ of the free water from wet solid waste and can achieve a drum loading of 245 pounds of dry salt per drum.

UNC Nuclear Industries, a subsidiary of United Nuclear Corporation, has developed an in-drum integrated volume reduction system (IDIVRS). The system 
was developed for liquid waste volume reduction and solidification using an epoxy binder. The system is small and compact and ideally suited for small waste generators. Liquid waste is fed into a DOT shipping container partially filled with hot epoxy resin. The drum is mounted with electric heaters and an insulating shroud, and topped with a mixer. Water vapor is discharged and a catalyst is added as a last step, resulting in a rock-like solid material after cooling. Upon removal of the mixer, heaters, and shroud, the drum is ready for capping and eventual disposal. Drum loading equivalent to 500 pounds of sodium sulfate with a polymer binder has been demonstrated. A larger integrated volume reduction system (IVRS) has also been designed using the same technology except for the use of a reaction vessel in place of the drum. The IDIVRS would cost about $\$ 30,000$, as compared to $\$ 1.5 \mathrm{million}$ for the larger IVRS. UNC also offers a dry waste solidification system (DWSS) for handling incinerator ash and calciner residue, for $\$ 750,000$. The DWSS is a three-component polymer process. A sodium silicate Portland cement process is another alternative available for radwaste solidification.

The Werner \& Pfleiderer Corporation's (WPC) volume reduction and solidification system combines drying and solidifying the wet radioactive waste. The evaporation and mixing take place in an extruder/evaporator heated with steam. The extruder/evaporator is a horizontal barrel with two motordriven rotating screws that intermesh. Waste and molten bitumen are simultaneously metered into the extruder/evaporator, where the free water is evaporated as the mixing occurs. The dry waste particles are embedded in the bitumen and discharged at the other end into a drum. The water vapor driven off from the waste rises through steam domes to condensers. Several WPC systems are in operation in Europe; WPC also operates a pilot plant in New Jersey. An equivalent drum loading of 335 pounds of salt is reported by the manufacturer. The WPC System Topical Report has received NRC approval. The estimated cost is around $\$ 600,000$.

A unique system called a pyro-converter has been developed by Penberthy Electromelt, Inc. This system consists of a pool of molten glass formed from crushed, nonradioactive waste glass and maintained at $2200^{\circ} \mathrm{F}$ by immersed electrodes. When waste is introduced at one end of this furnace, any water immediately evaporates and other volatiles are driven off rapidly. The 
introduction of air with excess oxygen over the molten pool ensures complete combustion; the solid residue falls into the pool, where it is incorporated into the glass. A small temperature gradient from one end of the furnace to the other causes the molten glass to flow very slowly from the feed end to the discharge end, where the glass/waste mixture can be drawn off into ceramicfiber-lined drums. The glass is periodically sampled to ensure a stable mixture, and soda is added as needed. A ful1-scale-model 13- by 22-ft furnace is operational in Seattle. The Mound Laboratory recently purchased a 3 - by $11-\mathrm{ft}$ pyro-converter at a cost of roughly $\$ 100,000$, including feed system and off-gas system modifications.

The Aerojet Energy Conversion Company's (AECC) volume reduction system uses a fluidized-bed dryer for liquids and a fluidized-bed incinerator for solid wastes. The fluidized-bed dryer is designed to accept feed of 10 to 25 $w t \%$ solids. The pH of the feed stream must be greater than 7 for proper control of bed size. In the dryer, the injected waste is atomized on the hot bed particles and the water is instantly vaporized. The bed containing the solid residue is occasionally removed by conveyor to a hopper. Solid waste is shredded and pneumatically fed into the fluidized bed incinerator. The incinerator's bed material is inert; air is blown in through the bottom to fluidize the bed particles, transport the waste, and provide combustion air. The ash residue is exhausted to the gas/solids separator and removed, unlike the residue from the fluidized-bed dryer. The ash from the incinerator and dryer product can be solidified with cement to give drum loadings of 400 pounds dry product per drum. The AECC has a full-scale prototype in Sacramento, California, and has logged about 2000 operating hours on the dryer and a few hundred hours on the incinerator. Aerojet markets the dryer and incinerator together for about $\$ 4.5$ milion.

\subsection{INC INERATION}

Combustible low-level radioactive waste makes up a major portion of the waste produced from nuclear power plants and research and medical institutions. A reduction in the final volume requiring disposal can save the generators substantial expense. Considerable experience with incineration has been accumulated in many countries and in the national labs in the U.S. The 
advantages and disadvantages of the major types of incinerator systems are presented in Table 5.2.

Trecan Limited of Canada produces an incineration system that includes a waste feed system, a primary pyrolysis chamber, an afterburner, an air dilution system, an air-to-air heat exchanger, a baghouse filter, and an induced-draft fan. This incineration system is in operation at the Bruce Nuclear Power Development site and at Chalk River. Both combustible solid and liquid waste can be processed in the incinerator. The primary vessel is a vertical chamber with a double-shell design, a grate at the bottom, and a loading door at the top. The waste is loaded in batches prior to ignition. During the burn, the temperature in the primary chamber is maintained at $1000^{\circ} \mathrm{F}$. Controlled-air incineration takes place; the pyrolyzed gases generated in the primary chamber are further oxidized in the afterburner at $1600^{\circ}$ to $1800^{\circ} \mathrm{F}$. Large objects continue to burn on the grate in the bottom of the primary chamber. When the burn cycle is finished, a cooling period follows and the ash is allowed to fall into a container. The flue gas from the afterburner is routed to an air-to-air heat exchanger after being airdiluted to $500^{\circ} \mathrm{C}$. The heat exchanger is constructed of stainless-steel tubes designed to further reduce the flue gas temperature to $200^{\circ} \mathrm{C}$ to meet the requirements of the cloth filters in the baghouse. The baghouse filters are frequently cleaned by a built-in mechanical shaker. Over $7000 \mathrm{~m}^{3}$ had been incinerated through 1980, resulting in a 40:1 reduction in volume from feed to ash. The final volume reduction factor is $23: 1$ after storage of the $2.5-m^{3}$ containers in engineered concrete trenches.

Combustion Engineering Inc. (C-E) offers a radioactive waste incineration system based on their full-scale prototype in Windsor, Connecticut. The C-E waste incineration system consists of a refractory-lined furnace and associated off-gas subsystem. The incinerator features excess air and suspension burning; grate burning for large, less reactive materials; constant air flow; and standard C-E fuel-firing equipment. Dry active waste is passed through a primary shredder, an air classifier, a cyclone separator, and a secondary shredder to reduce the material size to $1 / 8$ - to $1 / 4$-inch before being processed. Spent ion exchange resins, which have high initial activity levels, may also be fed to the incinerator as a slurry after being held for 
TABLE 5.2 Comparison of Incineration Systems

Volume Reduction System

Controlled-Air

Incinerator
Cyclone Drum Incinerator
Advantages

High flexibility of incinerating varying mixes

Good processing tolerance for small metal objects

No material added to process

Good capability for remote operation

Excellent ash containment in primary chamber

Complete combustion assured

Uses commercially available equipment

Flexibility in processing different types of waste

Ease of combustion rate control

Good flexibility of incinerating varying mixes

Will tolerate metal and noncombustibles

Combustion can be carried out in storage drum

No expensive fixed combustion process equipment
Disadvantages

Glass may soften and adhere to refractory

Ash removal not positive

Possible migration of radioactivity in refractory lining

Possible corrosion of off-gas system due to $\mathrm{HCl}$ if corrosion-resistant materials are not used

Manual ignition using torch or match to start

Sodium carbonate added for acid neutralization

Capability for remote operation only fair

Residue not completely inert

Particulate level high in off gas 
TABLE 5.2 Comparison of Incineration Systems (Contd)

Volume Reduction System

Fluidized-Bed Incinerator

Pyrolysis-Controlled Air Incinerator
Advantages

Good flexibility of mixes

of material

Good tolerance of glass

and metal objects

Dry-scrubber system and no liquid secondary waste

Refractory material not required

In-situ neutralization of $\mathrm{HCl}$ and other gases

Half the size of conventional incinerators

Improved combustion efficiency

Good capability for remote operation

Very reliable; requires little maintenance

Low particulates in the off gas

Long residence time in the secondary chamber

Controlled throughput for high-specific-activity waste
Disadvantages

Incomplete oxidation of wastes (C remains)

Small throughput even when operated continuousiy ${ }_{\text {added }}{ }_{2} \mathrm{CO}_{3}$ for bed must be

Catalyst of $\mathrm{Cr}_{2} \mathrm{O}_{3}-\mathrm{Al}_{2} \mathrm{O}_{3}$ burner

Feed material must be sorted and shredded

Nitrogen gas to regulate primary-bed combustion

Dry off-gas system produces secondary wastes of metal filters and HEPA filters

Residue is not inert due to some unoxidized $C$

Pilot model treats only combustibles

Possible corrosion of exposed metal surfaces 
TABLE 5.2 Comparison of Incineration Systems (Contd)

Volume Reduction System

Rotary-Kiln Incinerator
Advantages

No pretreatment of waste or shredding needed

Accepts a variety of waste forms

Remote operation and low operator exposure

Complete automatic ash removal

Continuous discharge of ash, preventing buildup

Rotating action enables more rapid and complete combination

Will accommodate tramp metal and glass

Can burn melted or liquid materials

Minimum radioactivity inventory in system (because of continuous ash remova l)

Industrially proven process

Average residence time of solids is $1 \mathrm{hr}$

Good capability for remote operation

Can process high feed rates
Disadvantages

Possible radioactivity migration into refractory lining

Difficult to maintain good seals on rotary kiln

Rotating kiln could result in shorter refractory life

May have incomplete graphite combustion

Possible radioactivity migration in refractory lining

High particulate concentration necessitates aircleaning equipment 
TABLE 5.2 Comparison of Incineration Systems (Contd)

\begin{tabular}{|c|c|c|}
\hline Volume Reduction System & Advantages & Disadvantages \\
\hline & $\begin{array}{l}\text { Dry off-gas system results } \\
\text { in no liquid waste }\end{array}$ & \\
\hline & $\begin{array}{l}\text { Maintenance and opera- } \\
\text { tions excellent }\end{array}$ & \\
\hline \multirow[t]{4}{*}{$\begin{array}{l}\text { Vitrification } \\
\text { (molten-glass furnace) }\end{array}$} & $\begin{array}{l}\text { Solidification occurs } \\
\text { simultaneously with } \\
\text { volume reduction }\end{array}$ & $\begin{array}{l}\text { Glass must be added in } \\
\text { process }\end{array}$ \\
\hline & $\begin{array}{l}\text { Can process any type of } \\
\text { waste form }\end{array}$ & $\begin{array}{l}\text { Chemical additives to } \\
\text { keep glass at optimal } \\
\text { mix }\end{array}$ \\
\hline & Simple to operate & $\begin{array}{l}\text { High operating tempera- } \\
\text { ture }\end{array}$ \\
\hline & & $\begin{array}{l}\text { Less waste in final } \\
\text { solidification agent per } \\
\text { lb than other volume } \\
\text { reduction processes }\end{array}$ \\
\hline
\end{tabular}


decay for long enough so that they can be treated as LLW. Liquid wastes are not processed in the incinerator but are fed to the quench tower, which serves as a spray dryer, using the hot off-gas stream to evaporate the water. The waste incineration system can accommodate commercially available waste solidification subsystems to package the resulting waste product for final disposal.

Chem-Nuclear/ATCOR, the U.S. affiliate for Kraftenlagen, a West German company, offers an incineration system based on that developed at the Julich Nuclear Research Center in West Germany. The present incinerator at Julich has a $100-\mathrm{kg} / \mathrm{hr}(220-1 \mathrm{~b} / \mathrm{hr})$ capacity and started operation in 1977 . The incinerator is a vertical chamber separated into a pyrolysis stage and a combustion stage. The waste can be processed without any pretreatment such as sorting or shredding, and noncombustible solids are not a problem. Liquid waste can be fed in directly or in containers along with solid waste. A feed system remotely dumps waste into the top of the incinerator where the waste is slowly pyrolyzed in a reduced-oxygen atmosphere. Movable paddles separate the two stages; small pieces of waste are allowed to fall into the lower combustion chamber. Excess air introduced into the combustion chamber through small holes in the paddles also cools the paddles. Complete combustion takes place in the lower stage at about $900^{\circ}$ to $1000^{\circ} \mathrm{C}$. The off-gas system is a hightemperature filter of a fleece-like ceramic material, an air dilution step, a metal filter, and a HEPA filter before final venting to the atmosphere. The incinerator at Julich is operated 5 days a week, in shifts of 8 to 9 hours. Volume reduction has typically been 100:1 before solidification with cement. A full-sized incinerator of this type would cost about $\$ 4$ million.

Associated Technologies Incorporated (ATI) offers an incineration system based on the controlled-air incineration program at Los Alamos. The incinerator is a commercially produced two-chambered, refractory-lined, controlledair incinerator. The waste is fed into the primary chamber, where it burns in a very nonturbulent environment at less than stoichiometric conditions. Volatile gases and other products of combustion pass through a flame port to the secondary chamber above the primary chamber. In the secondary chamber, high temperatures and excess air combine to completely burn any gases. The ash remains in the primary chamber, where a hydraulic ram is used to discharge the 
ash into a sump. The scrubbing solution from the wet off-gas system is mixed with the ash to form a slurry, which is then processed in the ATI solidification system. An optional dry-ash-handling system is also available. This incineration system has been installed and is operating at the Westinghouse Fuel Fabrication Plant in Columbia, South Carolina. Associated Technologies Incorporated has also delivered a controlled-air incinerator to the University of Maryland for use in burning institutional waste, and the operation has been reported to be excellent. The cost of ATI's incineration system ranges from $\$ 50,000$ to $\$ 150,000$.

NUKEM of West Germany markets a radwaste incineration system based on the research performed at Karlsruhe Nuclear Research Center in West Germany. Transnuclear, Inc., White Plains, New York, along with Werner \& Pfleiderer, represents NUKEM in the U.S. The TN-220 is a vertical-shaft, excess-air incinerator and can be sized to handle a feed rate of fifty to several hundred pounds per hour. The dry, solid, combustible waste is shredded and fed into the incinerator. At the end of the day, the ash is dumped into a glovebox and allowed to cool. If the incinerator were operated at full heat capacity, liquid wastes up to $50 \mathrm{~kg} / \mathrm{hr}$ could also be processed. The off-gas system developed at Karlsruhe uses porous ceramic filters, dilution with cooling air, and HEPA filters as the final step. The ceramic filters are composed of silicon carbide candles with tiny pores. Since 1971 , the $60-\mathrm{kg} / \mathrm{hr}$ incinerator at Karlsruhe has had over 25,000 hours of operations experience with an availability of $80 \%$ and a volume reduction of $68: 1$ before solidification of the ash.

Koch Process Systems (formerly Helix Process Systems) offers a volume reduction system that includes an incinerator, off-gas subsystem, scrub solution subsystem, and ash removal. The controlled-air incinerator has both primary and secondary chambers. The off gases are cooled in a quench column and the particulate is removed in a venturi scrubber. Then the off-gas stream is neutralized in a packed column and condensed. Final filtration is provided by HEPA filters after the elimination of water droplets and reheating. The ash falls from the primary chamber by gravity and is transferred pneumatically to a storage hopper. An optional wet-ash removal system is also available. 
The Newport News Industrial Corp.'s (NNI) volume reduction system uses a single, multipurpose fluidized bed. Although this system will handle liquid waste, combustible waste, ion exchange resin, and filter sludge, only one type of waste can be processed at any given time. The bed is composed of particles of an inert material unaffected by the composition of the waste. The ash produced from the incineration of solid waste is carried from the vessel to the off-gas system, where it is removed by the dry cyclone. Water vapor and other gases are removed in subsequent steps. Solidification can be accomplished by mixing the waste residues with cement, bitumen, or organic polymers. The company also offers a pelletizing process in which the dry product is mixed with a small amount of inorganic binder, compressed into 2.5-in.-diameter pellets, and then sealed with an epoxy coating. These pellets can then be stacked or packed randomly in drums. The NNI has operated a pilot plant in conjunction with Energy Incorporated at Idaho Falls for several years. Availability of the NNI system is uncertain. The Newport News Industrial Corp. has announced that they are no longer marketing radwaste treatment equipment.

United Technologies Corp., in cooperation with General Electric Co., has developed an inert-carrier radwaste process. This process evaporates all of the water in the waste by mixing a small amount of waste into a stream of hot inert fluid under highly turbulent flow. The dried residue is coated in suspension with a small quantity of high-melting epoxy resin and is then separated out.

Stock Equipment Company supplies a hospital incineration system that handles pathological and nuclear medical wastes and costs $\$ 350,000$. Waste is incinerated by partial pyrolysis in the primary chamber followed by complete combustion in the turbo-oxidation secondary chamber. The incinerator has the capacity to handle waste feed rates of 300 to $2000 \mathrm{lb} / \mathrm{hr}$ and 1 to $10 \mathrm{million}$ Btu/hr. Operation is highly automated, and an efficient energy recovery system is built in along with a multifuel capability.

\subsection{VOLUME REDUCTION CONSIDERATIONS FOR A WASTE CONSOLIDATION FACILITY}

The basic requirement for a waste consolidation facility should be a low-level radwaste compactor. The in-drum compactors available commercially 
are all acceptable and provide a fair amount of volume reduction with a minimum amount of expense and management. Considering the volume of discarded equipment that is generated by the Army, a shredder that can process metal would also be effective in further reducing the amount of disposal space required.

Volume reduction equipment such as dryers and incinerators can be combined in various ways depending on the waste being handled and the operating characteristics of the system. The majority of the methods discussed previously in this section can be sized and modified to meet the waste generator's specifications. In most instances, it is desirable to have both a dryer and an incinerator in a central facility that will handle the radioactive waste from many small generators. The exceptions are the cases of the Penberthy pyro-convertor (molten-glass furnace) and the ATCOR/Kraftenlagen incinerator, which will both handle DAW, liquid waste, and even small noncombustible objects with a minimum amount of pretreatment. For a small facility that is to serve only as a satellite, a compactor may be enough unless free liquid is involved. In the case of free liquid, which must be solidified or absorbed before burial, a small dryer is desirable.

The remaining factors to consider when choosing a volume reduction process are cost, volume reduction factor, simplicity of operation, maintainability, and licensing status. The prices for different dryers, incinerators, and other equipment vary widely. Volume reduction factors vary from process to process but are dependent on the waste type and the solidification agent used. High volume-reduction factors between 50 and 100 can be achieved with typical institutional waste with low specific activity. There is very little difference between processes with respect to the remaining factors, except that a few vendors have already had their topical reports accepted by NRC. The greater complexity of a fluidized-bed system may prove undesirable for simple LLW consolidation. 
. 


\subsection{WASTE MANAGEMENT OPERATIONS, EQUIPMENT, AND STAFFING}

The waste management operations of a central consolidation facility would begin with a survey of the incoming vehicle, an inspection of the cargo, and the off-loading of the cargo into the facility. The incoming vehicle would then be surveyed again and authorized to leave if not contaminated. The wastes received would be segregated according to the volume reduction operations to be used, and then processed. The resulting reduced waste volume would be packaged for disposal and placed in storage until there was a sufficient volume to make a full load for shipment to a disposal site.

The various types of equipment that would be needed in such a facility are discussed in this section, including waste-handling equipment, health physics equipment, and computer equipment for record keeping. Staffing needs are also reviewed.

\subsection{OVERVIEW OF FACILITY OPERATIONS AND WASTE-HANDLING EQUIPMENT NEEDS}

When radioactive waste is received at a waste consolidation facility, health physics instruments would be used to survey the truck, trailer, and contents in order to determine the radiation dose levels and ensure compliance with 49 CFR. Leak tests would also be performed before the material was removed from the truck, and the type of radiation would be checked against the bill of lading. The instruments required to perform these measurements are discussed in Section 6.2. Hand-pushed carts, forklifts, or overhead cranes would then be needed to unload the packages and move them to the initial receiving and segregation area (see Figure 4.1). Because the packages would be reconfigured during the move, dose levels should aga in be measured to determine whether temporary shielding is required around the operator during the transfer operation. Temporary shielding might also be required as the packages are logged in, segregated, and removed to the appropriate storage areas.

In the segregation area, where the waste would be sorted according to type (combustible, compactable, or liquid waste requiring processing by solidification or evaporation), overhead or walk-in hoods equipped with 
filtration devices should be provided to prevent the radioactive material from becoming airborne. Personnel would require protective clothing and appropriate dosimeters (discussed in Section 6.2). Clear polyethylene bags or cardboard boxes would be needed for segregating the waste if it was to be processed further.

A metal detector would be used to check the waste going to the incineration area if the incinerator was unable to process noncombustible objects. Any waste that was not to be processed further would be transferred to the final inspection and shipping area, where it would be inspected and labeled to ensure that it met burial ground requirements.

The feed systems for the volume reduction processes should be fully automated to maintain dose levels to personnel ALARA. A conveyor and/or mechanical arm could be used to feed DAW in plastic bags and cardboard boxes into the incinerator. A liquid injection system could be used to incinerate organic liquids, or the liquids could be burned in plastic containers along with the solid waste. Aqueous liquid waste should be pumped into a liquid storage tank and remotely fed to an evaporator or dryer. If not processed, the free liquid would be fed to the solidification system before shipment for disposal.

The processed waste would need to be handled carefully. The incinerated waste in particular would be so concentrated that the activity of a given volume of waste would be much higher that it had been previously. Therefore, a system would be needed to automatically convey the dry residue from the incinerator and evaporator/dryer to the solidification system if the residue was not in a stable form. If the dehydration equipment mixed in the solidification agent at the same time the waste was being dried, the waste residue could be mixed with a solidification agent directly in a drum or in a mixer and then transferred to drums using currently available druming stations with remotely operated turntables and remote or manual capping units. Health physics equipment would again be used to survey the drums containing the cooled and solidified radioactive waste, and all other processed waste, for surface contamination and to measure the radiation levels to ensure compliance with regulations. After inspection and labeling, the drums would be stored for final shipment to a burial site. 


\subsection{HEALTH PHYSICS EQUIPMENT AND SUPPLIES}

The main areas of concern in handling any radioactive materials are airborne radioactivity, radioactive contamination, and direct radiation. The equipment used to detect radiation and the protective clothing and radiation warning devices used to limit radiation doses to personnel are described below.

\subsubsection{Air-Sampling and Air-Monitoring Equipment}

Air sampling and air monitoring are performed to determine the presence and amount of radioactivity in the air. Air samplers collect the air to sample it for radioactive gases and particulates, or pull the air through a filter to sample it for radioactive particulates. Air-monitoring instruments analyze the air as it is collected.

\subsubsection{Air Samplers}

Airborne gases and particulates are removed from the atmosphere for analysis by grab samplers. A container with a vacuum inside is opened at the sampling location and then closed and removed for counting. The samples can be collected in glass bottles and analyzed later using gamma pulse-height analysis, or the container may have a built-in detector (e.g., a GeigerMueller (GM) tube inside a collecting cylinder). Gases and vapors can also be collected using special absorbers such as activated charcoal, silica gel, or alumina gel, which can be brought into contact with the sampled atmosphere and then analyzed. Activated-carbon cartridges are routinely used to check for radioiodine. Other particulate grab samples are taken with a high-volume air sampler: a large volume of air is drawn through a filter paper using a portable air suction pump, and the filter is then removed for counting.

Both the GM counter and the proportional counter operate on the principle that radiation ionizes matter (in this case, a gas) as it passes through the matter. In the case of the proportional counter, the number of ionizations produced depends on the type and energy of the radiation. The GM counter does not make such a distinction. Therefore, a GM counting system should be used only to determine the presence of radiation and to give an indication of 
radiation levels for the grab samples. A proportional counter in conjunction with a pulse-height analysis system should be used to determine the type and energy of the radiation.

Air samples should be taken periodically in the segregation and processing areas. Lapel samplers can be used to obtain breathing-zone samples while an individual moves about. They operate on batteries and consist of a small air pump and membrane or cellulose fiber filters in small holders.

\subsubsection{Air Monitors}

Continuous air monitors are used to monitor airborne radioactivity in a room or building. Portable air monitors are used in individual working areas. Air-monitoring systems have a counter (proportional or GM) near the filter paper or sample container used as the collecting medium. Air monitoring provides immediate sampling results, can indicate the need for evacuation when radiation levels exceed certain preset levels, and can be used for trend analysis. The air monitors used at a consolidation facility should be equipped with strip chart recorders and air activity meters, which usually read out in counts/minute per liter of air.

A limitation of most air monitors is that they cannot detect low levels of radioactivity. For example, an alpha air monitor used to measure depleted uranium may not respond immediately, and the air activity levels could be several times higher than the acceptable limits before the alarm sounds. Despite this limitation, continuous air monitors should be placed in the segregation, processing, and storage areas at breathing-level height in the locations that have the greatest probability for release. A portable air monitor could also be carried by each individual entering these areas if there was a significant potential for a release.

\subsubsection{Survey and Personnel-Monitoring Equipment}

Personnel working in a radiologically controlled area may become contaminated. To stop the spread of contamination to uncontrolled areas, all personnel should be surveyed and personnel-monitoring equipment should be provided at the exit from a controlled area. Hand and shoe monitors should 
also be placed near work areas and at exits. If the individual workers are to be responsible for monitoring themselves, they should be trained in proper survey procedures. Otherwise, a health physicist should be present.

A frisker is commonly used for personnel monitoring. The frisker is generally a rate meter with a pancake GM probe (a flat cylindrical probe that counts over a large surface area). This counter may or may not have a built-in alarm. Another device used to survey personnel as they leave work areas is a portal monitor. The older portal monitors were small-area GM detectors arranged on the frame of a doorway. They were typically unable to reliably detect personnel contamination until it was many orders of magnitude above the levels that can be detected with a frisker. The new highsensitivity portal monitors overcome some of these limitations by using large-area energy-dependent detectors (scintillation or gas-proportional detectors) that operate in a continuous background-subtraction mode. Table 6.1 provides a description of available high-sensitivity portal monitors.

Zinc sulfide alpha-scintillation probes are typically used to check for contamination on countertops and other surfaces. A scintillating material emits light when struck by radiation. This light output is converted to an electrical pulse, and the size of the pulse is directly related to the amount of radiation exposure.

\subsubsection{Equipment for Assessing Direct-Radiation Levels}

Portable survey instruments or remote area monitors are used to indicate real-time radiation levels, and personnel dosimeters are used to indicate the total amount of radiation to which a person has been exposed.

\subsubsection{Portable Survey Instruments}

An ion chamber in conjunction with an electrometer tube, an ammeter, and batteries makes up a portable device used to measure dose-equivalent rate. The ion chamber construction depends on the type of radiation to be measured (alpha, beta or gamma). The ion chamber operates on the same principle as the GM and proportional counter and can be used to distinguish among radiation types. Examples of ion-chamber survey meters are the Cutie Pie and rate meter. 
TABLE 6.1. Characteristics of High-Sensitivity Portal Monitors

\begin{tabular}{|c|c|c|c|}
\hline Portal Monitor & Detectors & Foot Monitor? & Counting Mode \\
\hline Eberl ine PM- 6 & $\begin{array}{l}11 \text { beta-sensitive } \\
\text { gas-flow proportional } \\
\text { detectors ( } P-10 \text { gas) }\end{array}$ & Yes & $\begin{array}{l}\text { Walk-through or stop- } \\
\text { count-go with vari- } \\
\text { able count time } \\
\text { (ultrasonic) }\end{array}$ \\
\hline IRT PRM-110 & $\begin{array}{l}2 \text { gamma-sensitive } \\
\text { liquid scintillant } \\
\text { columns }\end{array}$ & $\begin{array}{l}\text { Optional 3rd } \\
\text { detector }\end{array}$ & $\begin{array}{l}\text { Walk-through (in- } \\
\text { frared with op- } \\
\text { tional ultrasonic) }\end{array}$ \\
\hline $\begin{array}{l}\text { Measurements, } \\
\text { Inc. }\end{array}$ & $\begin{array}{l}\text { Multiple beta-sensi- } \\
\text { tive gas-flow pro- } \\
\text { portional detectors } \\
\text { ( } P-10 \text { or propane gas) }\end{array}$ & Yes & $\begin{array}{l}\text { Side-step-walk- } \\
\text { through (ultra- } \\
\text { sonic) }\end{array}$ \\
\hline $\begin{array}{l}\text { National Nuclear } \\
\text { Beta } 10\end{array}$ & $\begin{array}{l}3 \text { beta-sensitive gas- } \\
\text { flow proportional de- } \\
\text { tectors ( } P-10 \text { gas) }\end{array}$ & $\begin{array}{l}\text { Optional 3rd } \\
\text { detector }\end{array}$ & $\begin{array}{l}\text { Walk-through (ultra- } \\
\text { sonic) }\end{array}$ \\
\hline $\begin{array}{l}\text { National Nuclear } \\
\text { Gamma } 10\end{array}$ & $\begin{array}{l}3 \text { beta-gamma-sensi- } \\
\text { tive plastic scin- } \\
\text { tillation detectors }\end{array}$ & $\begin{array}{l}\text { Optional 3rd } \\
\text { detector }\end{array}$ & $\begin{array}{l}\text { Walk-through (ultra- } \\
\text { sonic) }\end{array}$ \\
\hline $\begin{array}{l}\text { Technical Assoc. } \\
\text { PPM-25GF }\end{array}$ & $\begin{array}{l}9 \text { beta-sensitive } \\
\text { gas-flow proportional } \\
\text { detectors }(P-10)\end{array}$ & Yes & $\begin{array}{l}1.6-\mathrm{sec} \text { count time } \\
\text { (photoce11) }\end{array}$ \\
\hline $\begin{array}{l}\text { TSA Systems } \\
\text { PMi- } 500\end{array}$ & $\begin{array}{l}11 \text { gamma-sensitive } \\
1-i n . \times 2 \text {-in. NaI } \\
\text { (TL) detectors (op- } \\
\text { tional 12th detector) }\end{array}$ & Yes & $\begin{array}{l}\text { 4- to } 6-\mathrm{sec} \text { count } \\
\text { time (infrared) }\end{array}$ \\
\hline
\end{tabular}

The GM survey meter consists of a GM tube and a count rate meter and should be used only to detect the presence of radiation. These survey meters are used to detect beta and gamma radiation. For very low energy beta $\left({ }^{3} \mathrm{H}\right), \mathrm{a}$ tube with a very thin covering (window) over one end of the detector needs to be used. Proportional counters are also used as survey meters because they can discriminate among different types of radiation. Sodium iodide (NaI) detectors are scintillation devices that have a high efficiency for gamma ray detection and measurement. They can be used as a portable survey meter or can be connected to a pulse-height analysis system to provide a gamma energy spectrum. 
Neutron-measuring devices would also be required at a consolidation facility. Survey meters to measure both fast and slow neutrons should be available. Table 6.2 provides example list prices of some health physics survey and counting instruments that would be needed at a consolidation facility.

TABLE 6.2. Sample List Prices for Health Physics Survey and Laboratory Counting Instruments

\begin{tabular}{|c|c|c|c|}
\hline Instrument & Cost Each & $\begin{array}{l}\text { Estimated } \\
\text { Quantity } \\
\end{array}$ & Total Cost \\
\hline $\begin{array}{l}\text { Alpha probe } \\
\text { Pulse rate meter } \\
\text { Ion chamber }\end{array}$ & $\begin{array}{r}\$ 440 \\
600 \\
995\end{array}$ & $\begin{array}{l}3 \\
3 \\
4\end{array}$ & $\begin{array}{r}\$ 1,320 \\
1,800 \\
3,980\end{array}$ \\
\hline $\begin{array}{l}\text { Gas-flow proportional } \\
\text { counter with scaler }\end{array}$ & 2,645 & 2 & 5,290 \\
\hline GM hand probe & 450 & 2 & 900 \\
\hline GM pancake probe & 185 & 2 & 370 \\
\hline GM thin-window probe & 65 & 2 & 130 \\
\hline Energy-compensation & 160 & 1 & 160 \\
\hline Radiation monitor & 585 & 3 & 1,755 \\
\hline NaI scintillation probe & 580 & 2 & 1,160 \\
\hline Pulse-height analys is system & 10,000 & 1 & 10,000 \\
\hline Neutron probe (fast) & 590 & 2 & 1,180 \\
\hline Neutron probe (slow) & 630 & 2 & 1,260 \\
\hline
\end{tabular}

\subsubsection{Remote Area Monitors}

Remote area monitors are fixed in place to measure radiation levels in a room. These monitors, usually ion chambers, sound an alarm if the radiation levels in the room exceed certain preset levels. They can be used as warning devices but do not provide an accurate or permanent record.

\subsubsection{Dosimeters}

There are basically three types of personnel dosimeters in use today: photographic-film dosimeters, pocket dosimeters, and solid-state dosimeters. The Army uses the film dosimeter for personnel monitoring. Film dosimeters 
consist of a thin silver halide emulsion spread on a thick support base of plastic. As radiation travels through the emulsion, the energy of the radiation reduces the silver ions to atomic silver, creating latent image centers. Chemical treatment of the film then causes the latent image centers to be reduced to metallic silver, which appears as a blackening of the film. The degree of darkening can be related to the radiation exposure. Film dosimeters (badges) provide a permanent record of radiation exposure.

Pocket ion-chamber dosimeters are often used in conjunction with a film badge. The dosimeter is roughly the size and shape of a fountain pen and contains a small quartz-fiber electroscope that forms a collecting electrode. The fiber is repelled by the electrode as they both acquire a like charge, and the image of the fiber can be viewed on a calibrated scale by either holding the pencil up to a light (direct reading) or inserting it into a device that measures the change in potential between the electrodes (indirect reading). An alarming-style pocket dosimeter gives off chirp-like sounds and/or light flashes that increase in rate as the radiation exposure rate increases. Pocket dosimeters provide an immediate readout (but not a permanent record) and should be worn by personnel at a waste consolidation facility.

Electrons within thermoluminescence dosimeters (TLDs) are trapped in higher energy levels when they are excited by radiation. If the TLD is heated, the trapped electrons return to the ground state, giving off their energy in the form of visible light. The quantity (intensity) of the light that is emitted can be directly related to the number of trapped electrons, which, in turn, is proportional to the amount of radiation. The TLD does not provide a permanent record but is advantageous in that it is small (chips) and can be placed on extremities. The TLD is not currently used by the Army as a personnel monitoring device.

\subsubsection{Protective Clothing and Other Supplies}

A waste consolidation facility should have change rooms where protective clothing would be put on, removed, and stored. Personnel working in the segregation and process areas should don coveralls, shoe covers, and gloves before entering the work area. Respiratory protective devices would probably 
not be needed under normal operating conditions but they should be available. Step-off pads should be placed in front of the change room doors, and all protective clothing should be removed before an individual re-entered the change room from the process area.

A personnel decontamination area should also be provided. A personnel decontamination kit should be assembled for field use, and supplies should be available at designated decontamination stations. Typical materials that should be included are listed in Table 6.3.

TABLE 6.3 Contents of Personnel Decontamination Kit

Item

Item

Applicators, cotton-tipped

Cotton balls

Cleansing tissues

Sterile gauze pads ( 2 in. $x 2$ in.)

Handbrushes

Masking tape

Plastic cups

Plastic cups

Plastic bags

Scissors

Surgical gloves (talced)

Flushing tube

Filter papers (for smears)

Hand cream

Soaps

Regular bar soap

Abrasive soap

Detergent (household laundry type)

Reagents

Household bleach

Potassium permanganate

Sodium bisulfite

EDTA (ethylenediamine tetraacetic acid) salts

Basin (for field use)

5-gal jug (for field collection of liquids)
Approximate

Quantity

$\begin{aligned} 500 & \\ 200 & \\ 4 & \text { boxes } \\ 400 & \\ 4 & \\ 1 & \text { roll } \\ 25 & \\ 25 & \\ 20 & \\ 1 & \text { pair } \\ 1 & \text { box } \\ 4 & \text { feet } \\ 1 & \text { box } \\ 1 & \text { jar } \\ 2 & \text { bars } \\ 1 & \text { bar } \\ 1 & \text { box } \\ 1 & \text { bottle } \\ 1 & \text { jar crystals } \\ 1 & \text { jar crystals } \\ 1 & \text { jar crystals } \\ 1 & \end{aligned}$

Al1 areas where drums and other containers are stored should be marked with radiation warning ropes and signs. Appropriate labels would also be 
required on packages and trucks before waste was transported to a burial site. Table 6.4 gives example 1 ist prices for selected signs and materials and for health physics supplies.

TABLE 6.4. Example List Prices for Health Physics Supplies

Supplies

Lead pigs

Warning rope

Self-stick labels

Cardboard warning signs

Cloth tape

Flat-bottom planchets

Disposable gloves

PVC (polyvinyl chloride) coveratis

Shoe covers (fits al1)

Cloth smears

Decontaminant
Cost

$\$ 2,000$

$20.00 / 100 \mathrm{ft}$

$10.00 / 100$

$20.00 / 100$

$15.00 /$ rol 1

$7.00 / 100$

$3.75 / 100$

10.50 each

2.75 each

$28.00 / 500$ smears

10.50/1-1iter bottle

\subsection{COMPUTER EQUIPMENT}

A computer should be installed to provide effective and efficient management of the waste consolidation facility. The computer would maintain records of 1) incoming waste shipments, 2) inventories of barrels or waste containers, and 3 ) processed wastes shipped to burial sites. In addition, radiation exposure records, equipment or supply inventories, and other accounting records should be maintained. Access to individual records would be immediate upon demand. The reporting function would be automaticaliy performed by the computer, including daily transactions, invoices as required, and monthly, yearly, and other interim reports. These reports could be sent to other computers over the telephone lines, providing almost immediate transfer of information. In addition, the computer could provide word-processing facilities, summaries presented in graphical format, and analysis routines, all contributing to its usefulness as a management tool.

A decision as to which type or size of computer system to use is complicated by the phenomenal growth in the computer field. The computer 
capability supplied 5 years ago by a large room full of computer equipment can now be obtained in a desktop personal computer only slightly larger than a typewriter. Three types of computer systems are available:

- a single-user personal computer

- a network or combination of personnel computers that communicate with each other

- a minicomputer that allows multiple users to access it simultaneously The three differ in cost and application. The basic capabilities that all provide are discussed below, followed by a brief assessment of their potential applications for a waste consolidation facility.

\subsubsection{Data Base}

The maintenance of large amounts of data or records is one of the primary purposes of a computer. A waste consolidation facility would produce records each time shipments were received, inventories were taken, wastes were consolidated or shipped out, dosimeters were read, etc. Computers could handle this data through a structured mechanism called a data base. The data base stores incoming information, keeps track of where it is, and retrieves the information within milliseconds. Reports are generated by providing requests for all data with certain characteristics. The data base retrieves all data and compares characteristics for a match. Those that match are included within the report. The time required to search all data and produce reports is usualiy only seconds or minutes. The data base is a necessary part of the computer system.

\subsubsection{Data Storage}

A physical storage medium must be available for the data base to store records or data on the computer. On a computer, the storage medium is commonly called a disk device. The size or storage capacity of the device must be specified. Using a projected figure of 250 waste shipments (both incoming and outgoing) per year, and adding to this sufficient capacity for analysis computer codes, dosimetry records, and system overhead, a minimum figure of about 5 Mbytes $(5,000,000$ bytes) for storage space is estimated. 
This suggests the need for a hard-disk system, of which the winchester-type drives are the most cost-efficient.

\subsubsection{Interactive Communications}

Communication to the computer should be via a cathode-ray tube (CRT) terminal. The CRT terminal with its display screen is versatile and easy to use.

When data from an incoming shipping report was entered into the computer, the screen would display the information needed with blanks or fields to be filled in. A simple check to make sure that numbers were entered correctly when a numeric value was required could be made by the terminal. Once all data for a shipment was typed on the screen, it could be rechecked visually and corrections could be made before the data was entered into the data base.

\subsubsection{Word Processing}

The computer should have a word-processing capability. This is commonly available for computers as software (a code that performs a function but is not a physical hardware component). Supplying the word processing function on the computer allows the rapid incorporation of pertinent data into letters, memos, or reports. It also allows the storage of important letters or information on a disk for retrieval when desired.

\subsubsection{High-Quality Printer}

The computer should have a hard-copy printer to print out data reports, shipping invoices, exposure records, inventories, and accounting reports; to allow the word processing of correspondence and letters; and to provide hard-copy output of graphs, histograms, and other graphic displays.

\subsubsection{Optional Features}

Graphics software would be a useful addition to a computer system. It can present data as graphs or histograms instead of just numbers, thus permitting management to view data, trends, and surmaries easily. In combination with statistical software, it would provide an important tool for 
analysis. Communications software that would enable the computer to communicate with other computers via telephone lines would also be a useful addition.

\subsubsection{Suggested Computer Systems}

A single-user personal computer supplied with a 5-Mbyte disk drive, data base software, a high-quality printer, and communications software would be sufficient to handle the management functions of a central consolidation facility and would be the least expensive alternative. Unfortunately, only one person could use it at a time, and it would be rather slow (as computers go) at performing multiple tasks.

A second option would be to combine a network of personal computers that could "talk" to one another. One computer would then be placed in each of the following areas: the initial-receiving station, the radiation-monitoring office, the final-inspection and shipping area, and the office area. One computer would contain the 5-Mbyte or larger disk and would store all records or data. The computer in the office area would contain the word-processing software. The unit in the radiation-monitoring office would be used to keep personnel exposure records. This arrangement would be effective and appears to be the trend for the future, but as of March 1983, communication among personal computers still needs to be improved.

The recommended option is a minicomputer with user access via CRT terminals. The physical computer would reside in the computer room. A multiuser operating system would allow everyone to use the computer simultaneously. This is the most versatile of the three options and would allow everyone access to all of the computer resources. A minicomputer would also provide for future expansion. It could be used to monitor consolidation processes, radiation levels, etc., and could be set up to automate their control.

\subsection{STAFFING NEEDS}

About seven people would be required to operate a central waste consolidation facility. Additional personnel would be needed to carry out maintenance (janitorial and laundry) services, but these positions are not 
expected to be full-time. The staff positions and brief descriptions of the roles are as follows:

- Facility Manager: The manager would be responsible for the operation and administration of the facility. As part of this responsibility, the manager would coordinate the central facility's activities with those of any satellite facilities, with depots shipping LLW to the central facility, and with the waste disposal sites.

- Health Physicist: The health physicist would be responsible for establishing and implementing radiation protection procedures, surveying incoming and outgoing vehicles, waste packages, and the facility, and verifying the content of each shipment.

- Health Physics Technician: The health physics technician would assist the health physicist in performing the required surveys, calibrating equipment, and analyzing samples.

- Waste Management Technician: The waste management technician would be responsible for operating the volume reduction equipment, packaging the waste, and storing the waste pending its shipment for disposal.

- Warehouse Workers: Two persons would be needed to assist the waste management technician. The warehouse workers would operate any heavy equipment such as a forklift or crane. They would assist in the waste volume reduction and waste packaging activities, and would unload and load vehicles for shipment.

- Clerk/Typist: The clerk/typist would provide the clerical support required to operate the facility and would be responsible for logging shipment manifest data into the computer and extracting it as necessary. About five people would be needed to staff a satellite facility. The requirements essentially would be the same as those described for the central facility, but because of the smaller waste volume needed, only one technician and one warehouse worker would be needed. 


\subsection{COST-BENEFIT ANALYSIS}

This section describes the volume of LLW currently generated by the Army and projects the volume that may be generated in the future. The costs of transporting and disposing of the waste are also considered. These volumes and costs are then used to assess the cost of a waste consolidation facility and the savings that would result from reducing the waste volume.

\subsection{WASTE VOLUME}

The volume of LLW shipped by the Army to commercial burial grounds has been declining for several years. In 1977, the volume had reached a high of $29,176 \mathrm{ft}^{3}$ of solid waste and $10,950 \mathrm{gallons}$ of liquid waste. Since 1977 , the amount of waste has dropped to an annual average of about $15,000 \mathrm{ft}^{3}$ of solid waste and 3500 gallons of liquid waste. This downward trend is shown in Table 7.1.

The composition of the waste has also been changing. Discarded equipment containing radioactivity made up more than $50 \%$ of the waste shipped for disposal in 1977 , but only $10 \%$ in 1981 . In the same time period, the percentage of LLW that is institutional (from radioisotopes used in medical and research facilities) has increased. The Army's policy of recalling equipment containing radioactivity from the field and disposing of it accounts for the large volume in previous years. The major contributor to the volume of waste generated in the future is expected to be institutional waste. (a)

The decrease in the total waste volume shipped in recent years has several causes. One is that the improper packaging, labeling, and documentation of wastes have caused some Army shipments to be banned from certain disposal sites for extended periods. Another is the temporary closure of several burial sites and the permanent closure of others. The volume of

(a) Tritium, which is currently the source of a significant portion of the activity, is expected to be an even greater contributor in the future. 
TABLE 7.1. Volume of Army Low-Level-Waste Disposal

\begin{tabular}{|c|c|c|c|c|}
\hline \multirow[b]{2}{*}{ Year } & \multicolumn{2}{|c|}{ Total Volume (a) } & \multicolumn{2}{|c|}{ Incinerable Volume } \\
\hline & Solid & Liquid & Solid & Liquid \\
\hline $\begin{array}{l}1976 \text { (Nov. and Dec.) } \\
1977 \\
1978 \\
1979 \\
1980 \\
1981 \text { (Jan. through Sept.) } \\
\text { TOTAL }\end{array}$ & $\begin{array}{r}2,350.1 \\
29,176.4 \\
15,561 \cdot 5 \\
16,671.1 \\
14,272.2 \\
11,061.2 \\
89,092.5\end{array}$ & $\begin{array}{r}240.0 \\
10,950.0 \\
4,250.0 \\
3,110.0 \\
2,020.0 \\
4,320.7 \\
24,890.7\end{array}$ & $\begin{array}{r}1,739.0 \\
15,620.3 \\
8,407.0 \\
12,312.9 \\
9,681.8 \\
9,781.2 \\
57,542.2\end{array}$ & $\begin{array}{r}0.0 \\
10,950.0 \\
4,250.0 \\
3,110.0 \\
2,020.0 \\
4,320.7 \\
24,650.7\end{array}$ \\
\hline
\end{tabular}

(a) Volumes are in cubic feet for solids, gallons for liquids.

radioactive waste generated by the Army in the future is expected to increase; however, the volume of processed or unprocessed waste shipped for disposal will fluctuate depending on what happens at the disposal sites. The shipments of $15,000 \mathrm{ft}^{3}$ of solid waste and $3500 \mathrm{gallons}$ of liquid waste averaged over the past 4 years will probably continue for the next several years. In the future, reducing the volume of LLW will play an important role in keeping the amount of waste shipped for burial from increasing very much.

\subsection{TRANSPORTATION AND DISPOSAL COSTS}

Transportation costs in terms of dollars per mile (one-way) have been escalating about $10 \%$ a year, as shown in Figure 7.1 , and will probably continue to do so in the future. Currently, the cost of one-way shipping is about $\$ 1.50 / \mathrm{mile}$ east of the Mississippi River and $\$ 1.86 / \mathrm{mile}$ west of the Mississippi River for shipments travelling more than 1000 miles. Because DOT regulations governing LLW are less stringent than the controls imposed by commercial burial grounds, any waste that conforms to burial site requirements will meet DOT's requirements and will not be affected by any extra transportation costs.

Burial costs have risen sharply since mid-1978, as shown in Figure 7.2. The burial charge for waste with dose rates below $200 \mathrm{mR} / \mathrm{hr}$ at the drum surface had risen from $\$ 9 / \mathrm{ft}^{3}$ at the end of 1980 to $\$ 17 / \mathrm{ft}^{3}$ at the end of 1982 


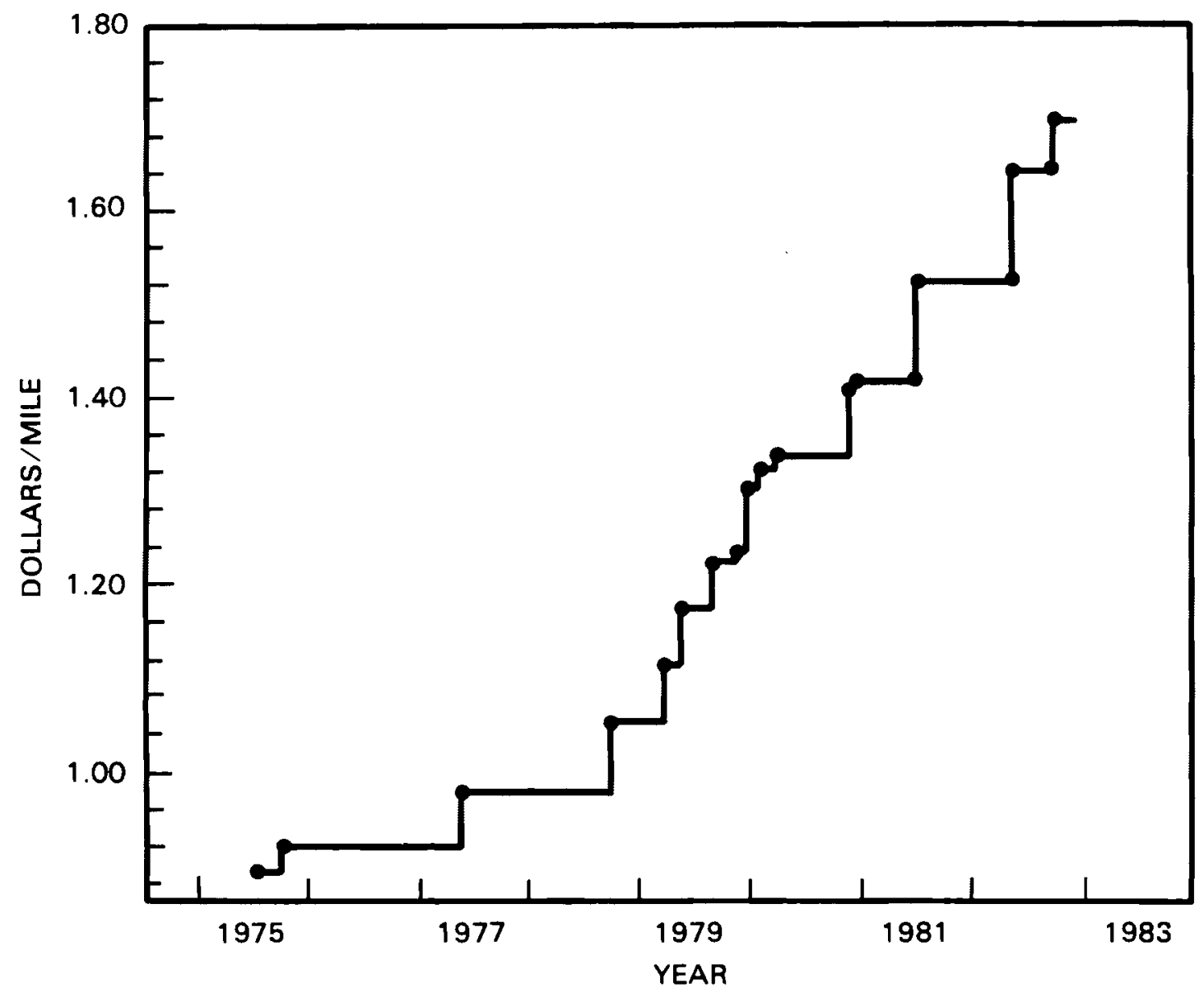

FIGURE 7.1 One-Way Shipping Charges for Low-Level-Waste Shipments Traveliing More Than 1000 Miles (single-driver, exclusive-use shipments) 


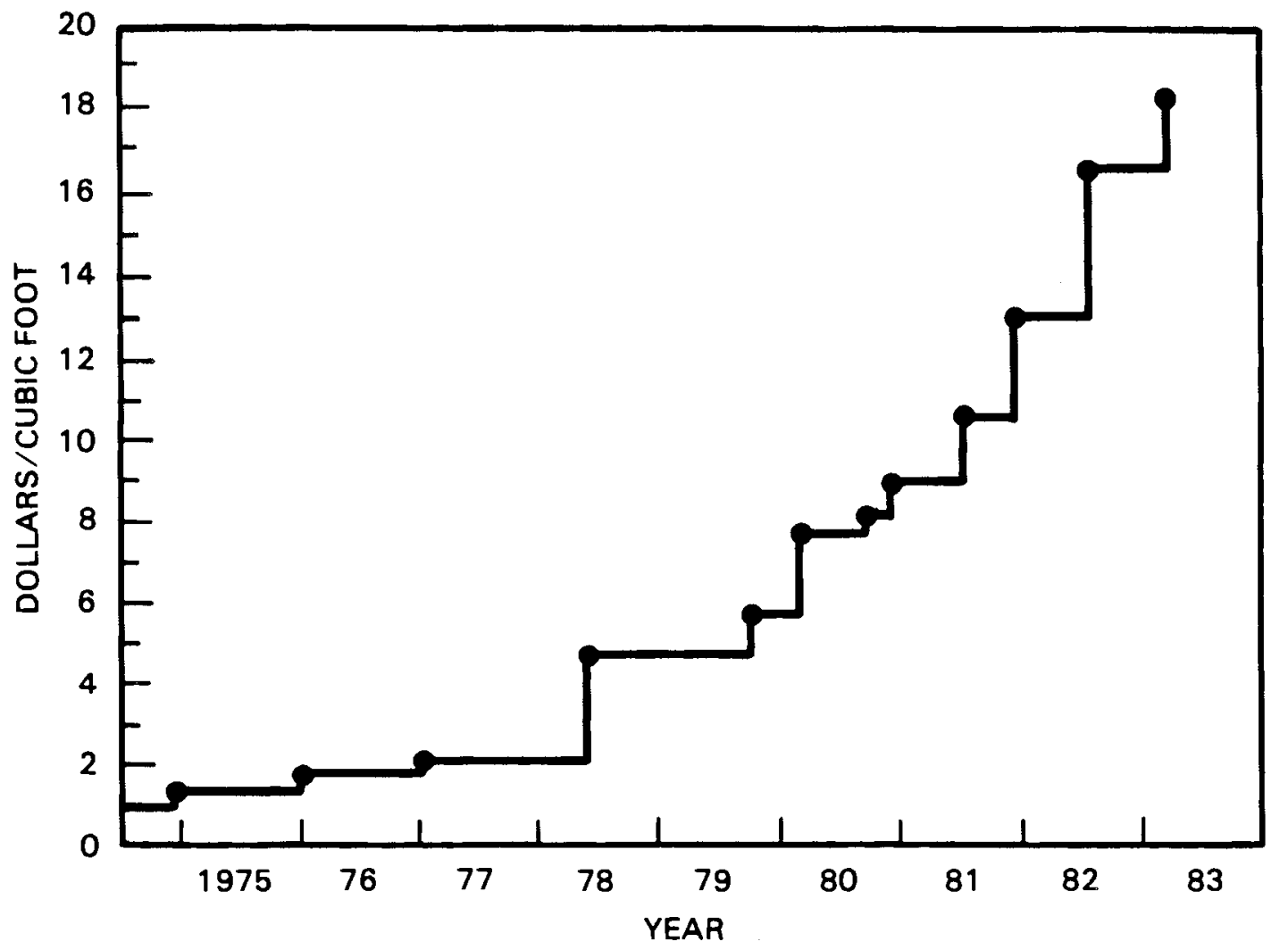

FIGURE 7.2 Buria1 Charges for Low-Level Waste (with dose rates at drum surface $<200 \mathrm{mR} / \mathrm{hr}$ ) 
(according to data from the U.S. Ecology Site at Hanford). As of March 1, 1983 , the cost rose again to $\$ 18.97 / \mathrm{ft}^{3}$. Disposal costs are likely to continue rising rapidly for another 5 to 10 years as disposal sites implement changes to meet new regulations. Costs for LLW disposal will be substantially affected by the new regulations contained in 10 CFR 61 , which will require several major changes:

- the segregation of compactable waste

- the deeper burial of Class B stable waste

- the introduction of engineered barriers to prevent inadvertent human intrusion into the burial site within 500 years after burial of the waste.

\subsection{FACILITY AND EQUIPMENT COST ESTIMATES}

The facility and equipment costs presented in this section are rough estimates of the total and annualized costs of constructing a new building (e.g., at Aberdeen) and retrofitting an old building (e.g., at Sierra) to provide waste consolidation facilities. The costs include the requisite equipment (incinerator, evaporator, etc.), in addition to the structure and its service facilities (air, water, lighting, HVAC, etc.)

Construction costs for a new facility were based on typical square-foot charges for buildings of a similar nature (e.g., research laboratories). Adjustments were made to the basic cost of the building to reflect special requirements (such as decontaminable walls, special shielding, elaborate HVAC equipment, etc.) associated with working with LLW. Equipment costs for a new facility were based on the following volume reduction equipment being used: an incinerator, a dryer/evaporator, a compactor, and a shredder. A solidification system to immobilize the reduced volume of waste, a computer system to handle records, and support and handling equipment are also included in the total equipment cost. (Support and handling equipment consists of drum carts, forklifts, sampling equipment, protective equipment, etc.) The costs for a new facility are shown in Table 7.2.

The construction cost for a retrofitted facility was estimated by developing individual costs for each of the required modifications. The 
retrofitted facility was designed to have all the same process equipment except the incinerator, and less support and handling equipment. The costs for the facility are shown in Table 7.3.

TABLE 7.2 Costs For Newly Constructed Facility (4th Quarter 1982 Dollars)

\begin{tabular}{|c|c|}
\hline Item & Cost \\
\hline \multicolumn{2}{|l|}{ Building } \\
\hline Nonprocess Area & $\$ 300,000$ \\
\hline \multicolumn{2}{|l|}{ Process Area } \\
\hline Structural & $1,300,000$ \\
\hline Service Facilities & 500,000 \\
\hline Equipment & $2,625,000$ \\
\hline Total & $4,725,000$ \\
\hline Fixed-charge rate & 0.14488 \\
\hline Annualized Capital Cost & 685,000 \\
\hline
\end{tabular}

TABLE 7.3 Costs For Retrofitted Facility (4th Quarter 1982 Dollars)

Item

Cost

Building

Structure

$\$ 220,000$

Service Facilities

180,000

Equipment

$1,375,000$

Tota 1

$1,775,000$

Fixed-charge rate

0.14488

Annualized Capital cost

257,000 
Annualized costs were calculated for both new and retrofitted facilities by applying a fixed-charge rate to the total capital costs. The fixed-charge rate is based on federal ownership with a discount rate of $7 \%$ and an economic life of 10 years. The annualized costs are shown in Tables 7.2 and 7.3. Several of the more important unit costs used to estimate both the new and the retrofitted building costs are given in Table 7.4. Estimated facility equipment costs are shown in Table 7.5.

TABLE 7.4 Unit Construction Costs for Major Building Components (4th Quarter 1982 Dollars)

Component

Basic Structure

Inside Walls (short)

Inside Walls (tall)

Suspended Ceiling

Metal Wall/Ceiling Covering

Epoxy Floor Covering

Poured Concrete Walls

HVAC Equipment

Nonprocess Area

Process Area

Cost
$\$ 40 / \mathrm{sq} \mathrm{ft}$ floor area
$25 / 1$ ineal ft
$50 / 1$ ineal ft
$2.50 / \mathrm{sq} \mathrm{ft}$ floor area
$5 / \mathrm{sq} \mathrm{ft}$ wall/ceiling area
$6 / \mathrm{sq} \mathrm{ft}$ floor area
$150 /$ cubic yd
$40 / \mathrm{sq} \mathrm{ft}$ floor area
$75 / \mathrm{sq} \mathrm{ft}$ floor area
$135 / \mathrm{sq} \mathrm{ft}$ floor area

TABLE 7.5 Facility Equipment Costs (1983)

Equipment

Incinerator ( $\$ 100 \mathrm{~K}-\$ 4 \mathrm{M})$
Dryer/Evaporator $(\$ 30 \mathrm{~K}-\$ 2 \mathrm{M})$
Solidification $(\$ 200 \mathrm{~K}-\$ 1 \mathrm{M})$
Compactor $(\$ 15 \mathrm{~K}-\$ 75 \mathrm{~K})$
Shredder $(\$ 15 \mathrm{~K}-\$ 75 \mathrm{~K})$
Support and Handling
Computer System ( $\$ 10 \mathrm{~K}-\$ 40 \mathrm{~K})$

Cost

$\$ 1,000,000$

500,000

465,000

75,000

45,000

500,000

40,000 
The costs associated with the disposal of radioactive waste that has not undergone volume reduction were compared with costs for the disposal of waste that has been treated by incineration, evaporation, and compaction, as in the proposed waste consolidation facility. The volume reduction factors used are very conservative, and greater factors are achievable. The most currently available burial costs were used for LLW that does not exceed $200 \mathrm{mR} / \mathrm{hr}$ at the surface of the container. The average transportation cost for this type of a container is currently $\$ 1.68$ per mile for shipments traveling $1000 \mathrm{miles}$ or more; therefore, a 1000-mile, one-way trip was used in the calculations to provide a basis for comparison. It should be recognized that the actual mileage would be much greater because most of the Army's waste is generated in the Aberdeen vicinity and shipped to the Hanford burial site. This additional mileage would result in a significantly increased savings that is directly proportional to the increase in mileage.

The results of these comparisons are listed in Table 7.6. Based on the above assumptions, a minimum savings of approximately $\$ 800,000$ per year can be realized. The actual potential savings may be two to three times greater depending on the actual distances traveled and volume reduction techniques used. Projections of savings in the future should take into account the average escalation in transportation costs and the very large increases likely in disposal costs. However, because of the difficulty in projecting the volume of waste from each site, the actual distances traveled, and the completion date of a consolidation facility (a factor that would significantly affect the burial and transportation costs), the estimation of the exact dollar savings would require a very lengthy process. 
TABLE 7.6 Cost Comparison for Disposal of Wastes With and Without Volume Reduction

Waste Volume/yr (a)

Drums/yr

Trips/yr (g)

Packaging Costs

(h)

Transportation Costs

Burial Costs $(j)$

Total Disposal Costs
Data and Costs Associated with Disposal of Wastes

\begin{tabular}{r}
$\begin{array}{r}\text { With Volume } \\
\text { Reduction }\end{array}$ \\
\hline $10,000 \mathrm{ft}^{3}$ \\
$5,000 \mathrm{ft}^{3}$ \\
$5,000 \mathrm{gal}$ \\
233 (c) \\
175 (e) \\
13 (f)
\end{tabular}

69

7

$\$ 116,194$

$\$ 10,946$

$\$ 162,288$

$\$ 16,464$

$\$ 635,850$

$\$ 59,900$

$\$ 914,332$

(a) Averages based on Table 7.1

(b) Based on a packaging efficiency of $50 \%$.

(c) Two-thirds of the solid waste incinerated, with a volume reduction factor of $6: 1$ after incineration.

(d) Liquid waste must be packed with enough material to absorb twice the amount of liquid present.

(e) One-third of the solid waste shredded and compacted, with a volume reduction factor of $4: 1$.

(f) Liquid waste dried, with a volume reduction factor of 9:1 after solidification.

(g) Average of 65 drums per trip.

(h) Cost of 55 -gal drums is $\$ 26 /$ drum.

(i) Average cost is $\$ 1.68 / \mathrm{mile}$ based on Tri-State Motor Transit Co. for a 1000-mile one-way trip. (The rate structure gives a constant $\$ / m i l e$ for any trip of 1000 miles or more.)

(j) Based on Hanford burial site rate of $\$ 18.97 / \mathrm{ft}^{3}(3 / 1 / 83)$ for drums with $200 \mathrm{mR} / \mathrm{hr}$ at drum surface. 



\subsection{REGULATORY IMPACTS}

This section briefly describes the impact of burial site requirements, proposed compacts, state and NRC regulations, and DOT regulations on the operation of an Army LLW consolidation facility and the ultimate disposal of the Army's LLW. These impacts are summarized at the end of the section.

\subsection{BURIAL SITE REQUIREMENTS}

Waste form requirements, as specified in 10 CFR 61.56, describe the minimum waste characteristics for waste to be acceptable for burial at a disposal facility. Section 61.56 imposes restrictions on waste explosiveness, pyrophoricity, etc.; the liquid contents of wastes; gaseous emissions from the wastes; biologic, pathogenic, or infectious materials; and waste packaging (packaging integrity and void spaces between the waste and the waste container). Regardless of who processes LLW for disposal--the waste generators, a consolidation facility, or the disposal site--the wastes would ultimately have to conform to the waste form requirements.

\subsection{COMPACTS}

The Army is working closely with proposed compact regions (see Figure 8.1) to provide for the disposal of Army LLW. In the absence of an agreement between the Army and the compacts, the Army would need to take into consideration the issues outlined in this section.

The major impacts of the formation of regional LLW compacts on the operation of a consolidation facility are difficult to predict. However, certain trends have been identified based on the congressional intent evident in the Low-Level Radioactive Waste Policy Act (P.L. 96-573), testimony from the senate field hearing held in Seattle, Washington, on the Northwest Compact Bill (S.2829, 97th Congress), and the views expressed at the National Conference on Establishing Regional Compacts for LLW Management, November 30-December 1, 1982, in Seattle, Washington. The major issues--state and regional LLW management, regulatory authority, import restrictions, and inspection provisions--are briefly discussed here. 


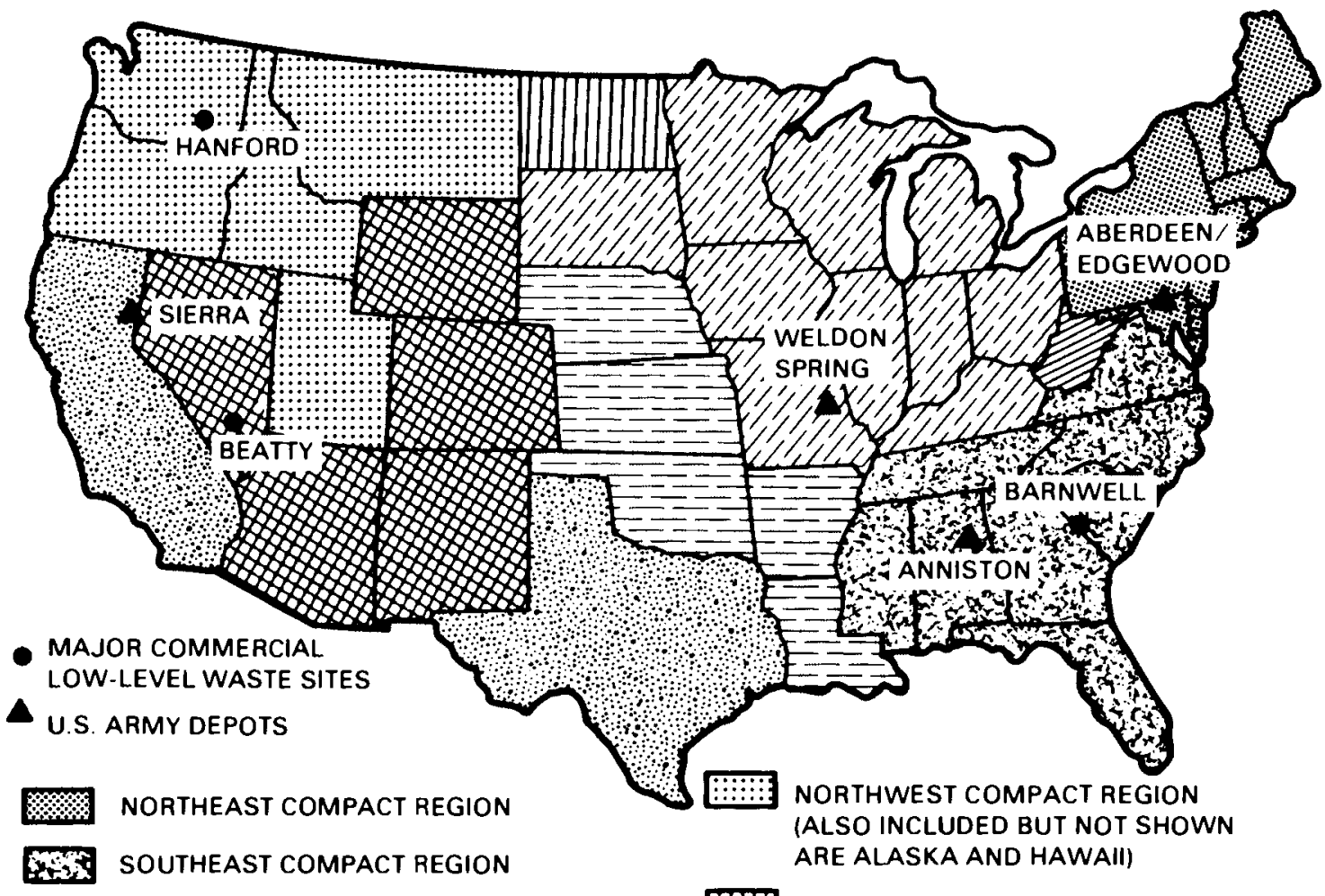

EZT MIOWESt COMPACt REgION

III NORTH DAKOTA WAS ORIGINALLY PART OF THE MIDWEST COMPACT
BUT HAS REJECTED THAT COMPACT

CENTRAL STATES COMPACT REGION

ROCKY MOUNTAIN STATES COMPACT REGION

WEST VIRGINIA (AND D.C., THE VIRGIN ISLANDS, PUERTO RICO) NOT A MEMBER OF ANY COMPACT, BECAUSE THE COMPACT THEY WERE PART OF DISBANDED.

TI STATES PURSUING INDEPENDENT COURSE

ELIGIBLE FOR BOTH NORTHEAST AND MIDWEST COMPACT REGIONS

FIGURE 8.1. Proposed State Compact Regions as of July 1983 


\subsubsection{State and Regional Low-Level-Waste Management}

All of the compacts proposed to date contain some provisions regarding the management of LLW. Such provisions will probably not be approved by Congress because 1) they clearly do not follow the congressional intent of the LLW policy act (i.e., that the management of LLW is a function of the federal government), and 2) they would significantly alter the existing federal/state regulatory framework. These provisions, through drawn-out state/congressional negotiation, could slow down the compact ratification process and push ratification and implementation beyond the 1986 exclusionary date. After 1986, operating waste disposal facilities within congressionally approved compact regions could exclude out-of-region wastes. Such action could leave waste generators and processors without an assured means of waste disposal.

\subsubsection{Regulatory Authority}

The proposed compacts contain other regulatory provisions, such as packaging and transportation regulations, that could affect waste generators and processors. Although the issue of waste management/waste disposal has a clear legislative record, these other regulatory issues do not. The various compacts may try to impose transportation and packaging regulations that could vary significantly from region to region. No clear consensus now exists as to the proper role of the states and compacts in overseeing these regulatory areas; however, DOE, NRC, and DOT representatives commented on these issues at the Northwest Compact hearings and asserted a strong federal presence in these regulatory areas. Senators Thurmond and Gorton have warned that there is strong congressional opposition to changes in the federal/state regulatory framework (Radioactive Exchange, Dec. 16, 1982). The situation is in a state of flux, and waste generators may have to comply with several sets of compact and state regulations.

\subsubsection{Import Restrictions}

Most of the proposed compacts contain waste importation restrictions that could have a major impact on the operation of a consolidation facility. Operating a consolidation facility raises several issues: 1) a region could ban the disposal of out-of-region wastes that the consolidation facility 
would process for shipment to its regional burial ground; 2) negotiation with the host compact region might be required to permit the disposal of out-of-region wastes; and 3) because regional waste export bans are probably unconstitutional (Article I, Sec. 10, U. S. Constitution), out-of-region wastes could probably at least be processed and stored at the consolidation facility. However, the ultimate disposal of such waste in the absence of negotiation is questionable, and a host compact might prohibit the shipment of waste from the consolidation facility to its burial ground.

\subsubsection{Inspection Provisions}

Another provision of some proposed compacts--onsite, unannounced inspections--could affect a consolidation facility's operations in two ways: 1) operations could be disrupted by such inspections, and 2) if certain activities at the facility required limited access because of national defense or security restrictions, compliance with onsite inspections might be difficult. Whether inspections would be required for waste generators shipping waste to the consolidation facility is questionable; such inspections would probably be unnecessary if the generators were shipping wastes that were packaged and transported to the consolidation facility in compliance with applicable regulations.

\subsection{STATE AND NUCLEAR REGULATORY COMMISSION REGULATIONS}

Most states and some localities have specific regulations concerning the packaging and transportation of hazardous waste and LLW. Table 8.1 (at the end of this section) summarizes the categories of regulations required by the different states (Fore 1982). This listing is current as of March 1982, but the area of waste regulation is changing rapidly. In considering the impacts of these regulations on a consolidation facility, the most problematical impacts include permit requirements for waste transportation into and out of the facility; routing bans or restrictions (e.g., in Maryland); and the required escort of waste shipments (e.g., in South Carolina). The impact of these regulations appears to be similar for the sites assessed; however, because the regulations change fairly often, this issue should be looked at again before the final selection of a site for a consolidation facility. 
Nuclear Regulatory Commission regulations would also have an impact on facility procedures. One effect of the regulations would be to require facility compliance with DOT and postal service rules for all waste shipments, not just interstate shipments ( 10 CFR 71 , Section 71.5 ). In addition, a quality assurance program would be required for the design, fabrication, assembly, testing, maintenance, repair, modification, and use of packaging ( 10 CFR 71 , Sections 71.24 and 71.51). Such a program might require extensive record keeping. Section 71.63 of 10 CFR permits NRC to make inspections that may be needed in addition to other inspections required by the host state or compact region. However, the NRC regulations do not appear to impose a large burden over and above the other pertinent regulations.

\subsection{DEPARTMENT OF TRANSPORTATION REGULATIONS}

The DOT placarding, packaging, and shipping regulations (49 CFR 171-173) are not expected to have major impacts on the operation of a LLW consolidation facility. The Army is al ready complying with these regulations in the shipping of its LLW from the waste generators directly to waste burial sites. The effect of these regulations on the operation of a consolidation facility is not expected to be greater than the compliance requirements for the waste generators. An added cost of the consolidation facility operation would be a program to train staff to operate the facility in compliance with the regulations. This impact could be mitigated substantially by locating the facility at a site that has previously trained shipping personnel, or by relocating trained staff.

\subsection{SUMMARY OF REGULATORY IMPACTS}

Proposed compact provisions appear to have the largest potential impact on the operation of a consolidation facility. They could even preclude a facility from processing wastes that originated outside the compact region in which the facility was located. Waste form requirements at the different burial sites also could affect the operation of a consolidation facility: the scope and type of activities performed at the facility would be directly affected by the waste generators' ability to comply with burial site 
requirements. State regulations, particularly transportation bans and routing restrictions, could affect the transportation of LLW to and from a consolidation facility; however, they would be unlikely to cause a heavy burden on facility operations. Finally, NRC and DOT regulations would probably not cause any greater impact on the operation of a consolidation facility than is now being borne by the waste generators. 


\section{TABLE 8.1. State Regulations on Low-Level Waste}

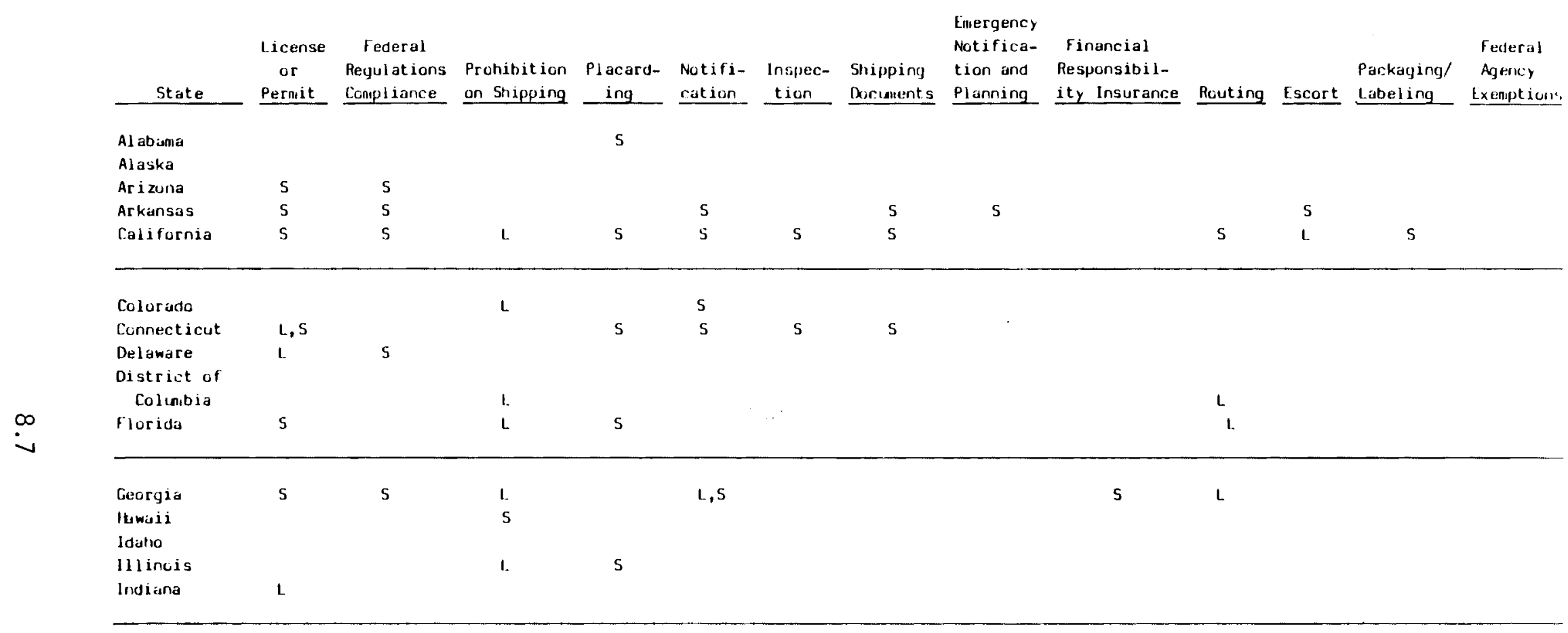

\section{KEY:}

S--state regulatiun

L--lacal urdinarices or reijulaticns promul gated by turnpike authorities, bridge comalissiuns, etc. 
TABLE 8.1. (contd)

\begin{tabular}{|c|c|c|c|c|c|c|c|c|c|c|c|c|c|}
\hline St.dte & $\begin{array}{c}\text { l.iourise } \\
\text { or } \\
\text { Pt:rinit } \\
\end{array}$ & $\begin{array}{l}\text { Federal } \\
\text { Regulations } \\
\text { Complinince } \\
\end{array}$ & $\begin{array}{l}\text { Pruluibition } \\
\text { om Smpping }\end{array}$ & $\begin{array}{c}\text { Platiard- } \\
\text { iliel__ }\end{array}$ & $\begin{array}{l}\text { Notifi- } \\
\text { cutisu! }\end{array}$ & $\begin{array}{l}\text { Inspet:- } \\
\text { tiun } \\
\end{array}$ & 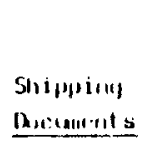 & 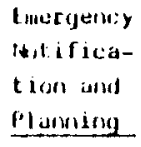 & $\begin{array}{l}\text { Iinancial } \\
\text { Responsihil- } \\
\text { ity lissurance }\end{array}$ & Phout ing & iscort & $\begin{array}{l}\text { Puckuging/ } \\
\text { lubuling }\end{array}$ & $\begin{array}{l}\text { rederal } \\
\text { Nulency } \\
\text { thenetions }\end{array}$ \\
\hline Iowa & s & s & & & & s & & S & & & & & \\
\hline Kansiss & & & & & & & & $s$ & & & & & \\
\hline Keritix:ky & $\mathbf{S}$ & $S$ & & & & & & & & & & & \\
\hline I. wuisiana & 5 & $s$ & & $\mathbf{s}$ & & & $\mathbf{s}$ & $s$ & $\mathbf{s}$ & & & & \\
\hline Moine & $L, S$ & & & 5 & & & $s$ & $\mathbf{S}$ & & & & & \\
\hline Harylaund & $L, S$ & s & $t$ & & L & & & & : & s & & $\mathbf{s}$ & \\
\hline Hossidiusetts & I. & $1 ., 5$ & 1. & $s$ & & & & & & & & & \\
\hline Hathiyall & 5 & s & I. & 5 & & $\mathbf{s}$ & & s & & & & s & \\
\hline Mindesuta & & s & & & & & & & & & & & \\
\hline 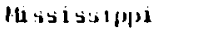 & & & & & & & & & & & & & \\
\hline Messuute 1 & $\mathbf{s}$ & & & & & & & & & & & & \\
\hline
\end{tabular}

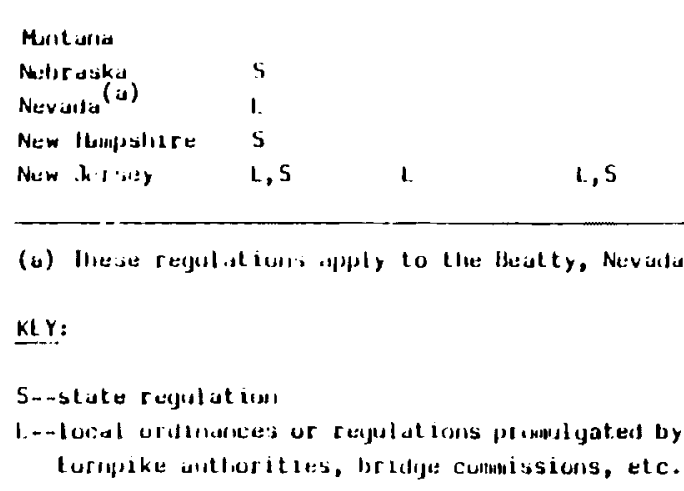




\section{TABLE 8.1. (contd)}

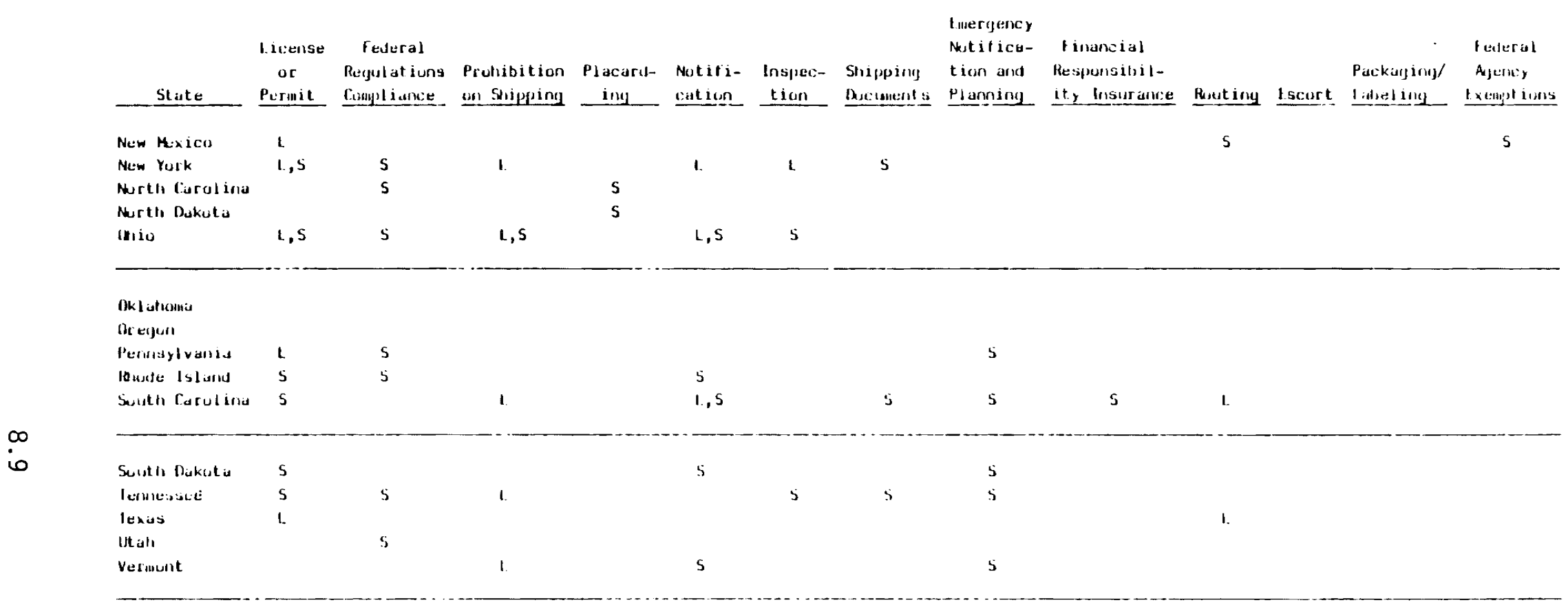

KLY:

S--stale regulatiun

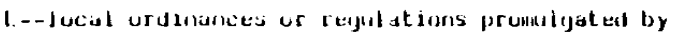

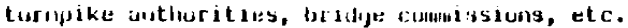




\section{TABLE 8.1. (contd)}

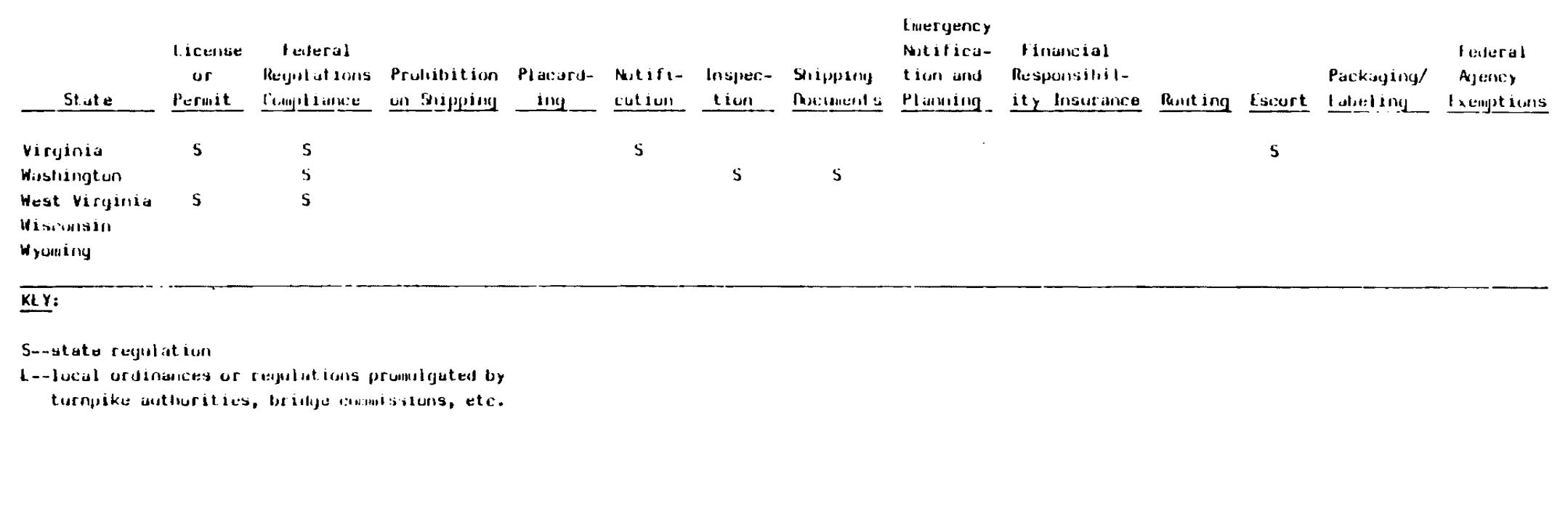


APPENDIX A

SITE VISIT CHECKLIST 
I. PROXIMITY AND ACCESSIBILITY

1. Is the site accessible to shipment by

a. auto, truck

b. air

c. rail

d. other (specify)

2. Will the majority of the shipping be vehicular?

3. Roads leading to the site are
a. city
b. county
c. state

4. Roads leading to the site are
a. well maintained
b. in good condition
c. in poor condition

5. Average commuting distance to site one way
a. $40-60$ miles
b. $20-40$ miles
c. 10-20 miles
d. less than 10 miles

6. How far are most (greater than $50 \%$ ) of the waste generators from the site?

a. less than 500 miles

b. 500-1500 miles

c. greater than 1500 miles

7. Will transport routes pass close to major cities?

8. What is the longest time waste would be in transit from waste generators?

a. 1-2 days

b. 2-5 days

c. more than 5 days

9. How far is the LLW burial site from the site?

a. less than 500 miles

b. 500-1500 miles

c. greater than 1500 miles

10. What is the longest time waste would be in transit to LLW burial?
a. 1-2 days
b. 2-5 days
c. more than 5 days 
II. FACILITY AVAILABILITY

1. Building primary purpose:

a. warehouse

b. production

c. administration

d. other

Comments: (i.e., multiple purposes - laboratory and administrative)

2. Building foundation:

a. concrete slab

b. basement

c. footing

d. other

Comments:

3. What are the foundation load limits (pounds per square foot)?

4. Type of building frame:

a. wood frame

b. masonry/concrete

c. metal

d. quonset

e. other

Comments:

5. Does the building need repair?

Comments: Indicate type of repair (e.g., roof needs repair)

6. Are offices present?

If yes, how many offices?

7. Is there laboratory space present?

8. Will modifications need to be made for a counting lab? Comments: (e.g., shielding)

9. Is the facility contaminated? Comments:

10. Is there a crafts shop either onsite or within the building?

11. Are there storage areas present?

If yes, number of storage areas

a. large (1arger than $\left.20^{\prime} \mathrm{L} \times 20^{\prime} \mathrm{W} \times 12^{\prime} \mathrm{H}\right)$

and size

b. small (smaller than $10^{\prime} \mathrm{L} \times 10^{\prime} \mathrm{W} \times 12^{\prime} \mathrm{H}$ )

c. moderate (between $a$ and $b$ dimensions) 
12. Does the building have loading/unloading docks?

13. Does the building have an air filtration system? Comments: (e.g., central or separate, condition, etc.)

14. Is there a security fence around the building?

15. Does the building have active security?

16. Does the building have water service?

17. Does the building have heating/cooling?

18. Does the building have ventilation?

19. Does the building have an overhead sprinkler system?

20. Do the floors have drains?

21. Are there liquid holding tanks present in or near the building?

22. Is there radiation detection equipment present? Comment: (type, purpose)

23. Is there a crane in the building? Comment: (type, ton limit)

24. Is there any volume reduction equipment present?

a. incinerator

b. compactor

c. evaporator/dryer

d. crystallizer

25. Does the building have rail access?

\section{I. RESOURCE AVAILABILITY}

1. Are people available to staff the facility?

a. Health Physicist

b. Quality Assurance Specialist

c. Warehouse workers

d. Clerical workers

2. Are waste packaging and shipping materials available at the site?

2a. Are material suppliers located near the site? Where: 
3. Are office and laboratory supplies available at the site?

3a. Are suppliers located near the site? Where:

4. Is health physics equipment available at the site?

4a. Are suppliers located near the site? Where:

5. What is the utility capacity?

6. Is fuel storage available for waste processing and onsite transportation operations?

IV. INSTITUTIONAL CONSIDERATIONS

1. Does more than one organization have responsibility for major site activities?

2. Does state or local opposition exist to nuclear facilities?

3. Are building codes, environmental regulations, and transportation restrictions on hazardous materials sufficiently stringent to prevent or delay construction or operation of the facility?

V. ENVIRONMENTAL CONSIDERATIONS

1. Is the site susceptible to flooding?

2. Is the site in a tornado region?

3. Is the site in a hurricane region?

4. Is the site likely to be impacted by earthquakes?

5. Is the site within five miles of a lake or river?

6. What is the prevailing wind direction?

7. Is the general topography hilly? 
SITE SKETCH

Site Name:

A. 5 
BUILDING SKETCH

Site Name:

Building Identification Code

Building Dimensions: Length

Width

Height

A. 6 


\section{REFERENCES}

Code of Federal Regulations, Title 10, Part 20, "Standards for Protection Against Radiation."

Code of Federal Regulations, Title 10, Part 61, "Licensing Requirements for Land Disposal of Radioactive Waste."

Code of Federal Regulations, Title 10, Part 71, "Packaging of Radioactive Materials for Transport and Transportation of Radioactive Material Under Certain Conditions."

Fore, Cathy S. 1982. Radioactive Waste Technology Newsletter. Radiation Effects Information Center, Oak Ridge, Tennessee.

Low-Level Radioactive Waste Policy Act. Public Law 96-573. 1982.

National Governors' Association, Task Force on Low-Level Radioactive Waste Disposal. 1980. Final Report.

The Radioactive Exchange, Vol. 1, Nos. 18 and 19. November 30/December 16, 1982. E. L. Helminski, publisher, P.0. Box 9528, Washington, D.C.

Spellman, J. 1982. "Testimony of Governor John Spellman Before the U. S. Senate Committee on the Judiciary, University of Washington, Seattle, Washington, 1982."

U. S. Department of the Army (DA). 1982. Installation Environmental Impact Assessment of Anniston Army Depot, Anniston, Alabama. Anniston, Alabama.

U. S. Department of the Army (DA). Materiel Development and Readiness Command. 1978. Installation Environmental Impact Assessment. Fourth edition. Aberdeen Proving Ground, Maryland.

U.S. Department of the Army (DA). Materiel Development and Readiness Command. 1979. Installation Environmental Impact Assessment, Sierra Army Depot, Herlong, California. June 15, 1979, revision of August 1976 publication. Herlong, CaTifornia.

U. S. Department of the Army (DA). Office of Dept. of Army Project Manager for Chemical Demilitarization and Installation Restoration. 1976. Assessment of Weldon Spring Chemical Plant in St. Charles County, Missouri. Aberdeen Proving Ground, Maryland. 


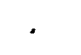

.

.

. 


\section{DISTRIBUTION}

No. of

Copies

OFFSITE

50 Commanding Officer

U.S. Army Armament Materiel Readiness Command

Attention: PRSAR-SF, Mr. Byron Morris

Rock Island, IL 61201

27 DOE Technical Information Center

R. L. Gilchrist

Hydro Nuclear Services

Richland, WA 99352

D. W. Murphy

Reynolds Electric and

Engineering Company

Las vegas, NV
No. of

Copies

ONSITE

DOE Richland Operations Office

H. E. Ransom

22 Pacific Northwest Laboratory

J. L. Baer

J. B. Brown

T. H. Essig

L. G. Faust

J. C. Gillings

W. A. Glass

C. D. Hooker

O. M. Lyso

J. Mishima

B. L. Murphy (3)

J. M. Selby

S. L. Stein

J. E. Tanner

Publishing Coordination (2)

Technical Information (5) 
.

, 